IZA DP No. 7259

Education, Social Mobility and Religious Movements: A Theory of the Islamic Revival in Egypt

Christine Binzel

Jean-Paul Carvalho

March 2013 


\title{
Education, Social Mobility and Religious Movements: A Theory of the Islamic Revival in Egypt
}

\author{
Christine Binzel \\ Heidelberg University \\ and IZA \\ Jean-Paul Carvalho \\ University of California, Irvine
}

Discussion Paper No. 7259

March 2013

\author{
IZA \\ P.O. Box 7240 \\ 53072 Bonn \\ Germany \\ Phone: +49-228-3894-0 \\ Fax: +49-228-3894-180 \\ E-mail: iza@iza.org
}

Any opinions expressed here are those of the author(s) and not those of IZA. Research published in this series may include views on policy, but the institute itself takes no institutional policy positions. The IZA research network is committed to the IZA Guiding Principles of Research Integrity.

The Institute for the Study of Labor (IZA) in Bonn is a local and virtual international research center and a place of communication between science, politics and business. IZA is an independent nonprofit organization supported by Deutsche Post Foundation. The center is associated with the University of Bonn and offers a stimulating research environment through its international network, workshops and conferences, data service, project support, research visits and doctoral program. IZA engages in (i) original and internationally competitive research in all fields of labor economics, (ii) development of policy concepts, and (iii) dissemination of research results and concepts to the interested public.

IZA Discussion Papers often represent preliminary work and are circulated to encourage discussion. Citation of such a paper should account for its provisional character. A revised version may be available directly from the author. 


\section{ABSTRACT \\ Education, Social Mobility and Religious Movements: A Theory of the Islamic Revival in Egypt ${ }^{*}$}

This paper examines the economic origins of the Islamic revival that took place in Egypt in the 1970-80s, and in Muslim societies more generally. We provide the first systematic evidence of a decline in social mobility among educated youth in Egypt. Developing a behavioral model of religion, we then characterize conditions under which a temporary decline in social mobility produces a large and long-lasting rise in religious participation. Religion in our model helps to cope with loss, which occurs when one's consumption falls below an expectations-based reference point. The model provides an explanation for why the educated middle class were in the vanguard of the Islamic revival. Rather than undermining religious belief and participation, our analysis suggests that economic development can make societies more prone to religious revivals.

JEL Classification: D10, D63, I24, J24, J62, O10, Z12, Z13

Keywords: Islamic revival, education, social mobility, inequality, social movements, Egypt

Corresponding author:

Jean-Paul Carvalho

Department of Economics

University of California, Irvine

3151 Social Science Plaza

Irvine, CA 92697

USA

E-mail: jpcarv@uci.edu

\footnotetext{
"This draft is a substantially revised amalgam of two earlier papers, "A Theory of the Islamic Revival" by Carvalho and "Decline in Social Mobility: Unfulfilled Aspirations among Egypt's Educated Youth" by Binzel. It supersedes them. The authors are indebted to Peyton Young, Ragui Assaad, Abigail Barr, Ken Binmore, Sam Bowles, Carlos Bozzoli, Dietmar Fehr, Paul Glewwe, Marwan Khawaja, Dorothea Kübler, Timur Kuran, John Quah, Michael Sacks, Thomas Schelling, Thomas Siedler, Douglas Staiger, Viktor Steiner, Francis Teal, Christopher Wallace, as well as seminar/conference participants at the University of Oxford, Santa Fe Institute, the Association for the Study of Religion, Economics and Culture, the Institute for Humane Studies, Heidelberg University, IZA, Dartmouth, DIW Berlin, Goethe University Frankfurt, the Berlin Network of Labour Market Research (BeNA), the 2011 NEUDC Conference, the 2011 Annual Conference of the German Economic Association Annual Conference, and the 2011 EEA Meetings. Carvalho gratefully acknowledges financial support from the Commonwealth Bank Foundation in the form of a John Monash scholarship and the Institute for Humane Studies. The usual caveat applies.
} 


\section{Introduction}

Since the 1970-80s, Egypt has undergone a cultural transformation, a rise in religious participation and identification that has been mirrored across Muslim societies. This Islamic revival reversed previous trends toward secularization in Muslim societies and runs counter to the secularization thesis that once held sway among social scientists. ${ }^{1}$ Beliefs and institutions which emerged in largely illiterate pre-industrial societies were supposed to be maladapted to and readily abandoned in a world of science, industrialization and improving standards of living, that is to say the modern world. ${ }^{2}$ Yet, since the 1970 s, there has been "an impressive revival of emphatically religious commitments... of vast geographical scope, affecting every single Muslim country from North Africa to South-East Asia" (Berger 1999, p. 7). Among other things, Islamic groups have formed government or gained substantial political power in Iran, Turkey, Pakistan, Egypt, Tunisia, Malaysia, Lebanon, Jordan and the Sudan. ${ }^{3}$

This paper develops a theory of the Islamic revival in Egypt. There is good reason to focus on Egypt. Egypt is the epicenter of the Arab world's various Islamic movements. The Egyptian Muslim Brotherhood set up or inspired Islamic organizations in Syria, Jordan (Islamic Action Front), Lebanon (Jamaa Islamiya), Algeria (Movement for the Society of Peace), Tunisia (alNahda), the Palestinian territories (Hamas) and Yemen (al-Islah). Parliamentary elections held a year after the revolution revealed the scale of support for Islamic political parties - the Muslim Brotherhood Freedom and Justice Party and the Salafist Al-Nour party attracted $47 \%$ and $28 \%$ of the vote, respectively. Results from the World Values Survey suggest that Egypt is one the most religious nations on earth: 98.4\% of Egyptians surveyed in 2000 describe themselves as a religious person and $99.7 \%$ report drawing comfort and strength from religion (WVS, 2009). ${ }^{4}$

\footnotetext{
${ }^{1}$ Political moves toward secularization in countries such as Turkey, Iran, Egypt and Syria coincided with a popular shift away from religious activity and values. By the 1930s, as Albert Hourani writes, Islam was more an inherited culture than a source of practical guidance for a large part of the educated elite in Muslim societies; among them prayers and fasting were less frequently observed, and the consumption of alcohol was rising (Hourani 2005, p.345-6).

${ }^{2}$ Voltaire, Jefferson, Marx, Comte, Muller, Spencer, Durkheim, Weber and Freud all espoused some version of this secularization thesis. See Stark (1999), Berger (1999), Wallis \& Bruce (2001) and Norris \& Inglehart (2004).

${ }^{3}$ There are a number of studies which document an increase in religious belief and participation in Muslim societies. See for example Mutlu (1996) on Turkey and Shadid (1988) on the Palestinian territories.

${ }^{4}$ The results are based on the Muslim subsample (94\% of respondents). In the World Values Survey of 2008, slightly fewer Muslims (92.4\%) describe themselves as a religious person. In both waves, more than $95 \%$ of Muslims state that religion is "very important" to them (on a four-point Likert scale).
} 
In this paper, we explore the economic origins of the Islamic revival in Egypt. The argument proceeds in three steps. Firstly, we point to existing evidence that the educated middle class were in the vanguard of the Islamic revival. This was not a movement of isolationist religious sects, but a broad-based revival driven by educated and talented members of society. Secondly, we conduct an empirical analysis of trends in Egyptian educational and occupational mobility drawing on nationally-representative household survey data. We show that while there has been a marked increase in educational attainment across social strata, social mobility among the educated has declined. Thirdly, we develop a formal model in which a (once-off) decline in social mobility can lead to a permanent and widespread rise in religious participation, led by the educated middle class. Rather than undermining religious belief and participation, our analysis suggests that economic development can make societies more prone to religious revivals.

The basic structure of the model is as follows. Individuals invest in education and form aspirations, which are modeled as endogenous expectations-based reference points. Based on their level of education and socio-economic background, individuals are assigned to either a high or low wage occupation. After their occupation is determined, individuals divide their time between work and religious participation. Finally, individuals experience unfulfilled aspirations if their consumption falls below their reference point.

Several authors, most notably Ayubi (1991), Amin (1995) and Wickham (2002), have suggested that Egypt's Islamic revival was fueled by feelings of relative deprivation, especially among educated youth. ${ }^{5}$ We make two contributions to this literature. Firstly, we are the first to present systematic evidence of a decline in social mobility among educated youth in Egypt over the 1970-1990 period. Prior work has relied upon anecdotal and suggestive evidence. Secondly, we are the first to develop a formal model of religious movements based on unfulfilled aspirations. In doing so, we make use of advances in behavioral economics in analyzing reference-dependent preferences (see Kahneman \& Tversky 1979, Köszegi \& Rabin 2006). Beginning with a neoclassical model of labor supply, we introduce agents with endogenous expectations-based reference points. Unfulfilled aspirations are treated as a form of loss aversion. Contrary to the relative deprivation literature, an increase in unfulfilled aspirations does not necessarily lead to a rise in religious participation. Instead, individuals

\footnotetext{
${ }^{5}$ According to Runciman (1966, p. 10), person $i$ experiences relative deprivation of object $X$ when $i$ wants but does not have $X$, and $i$ sees some other person(s), which may include himself at some previous or expected time, having $X$ (whether or not this is or will be the case).
} 
may work harder to reach their reference point, spending less time on religion. We call this the living-up-to-expectations $(L U E)$ effect. For a rise in unfulfilled aspirations to lead to a religious revival, something else is required: religious groups need to provide more than leisure and social interactions (their usual roles in models of religion), but also perform a psychological function in helping individuals cope with unfulfilled aspirations. In this case, we derive a simple necessary and sufficient condition under which unfulfilled aspirations lead to increased religious participation. It turns out that inequality, social mobility and poverty cannot be viewed in isolation, but are jointly linked to religious participation in a specific way. Finally, we show how standard motivations for religious participation (e.g. social service provision) can interact with psychological motivations to produce a large and permanent increase in religiosity in response to a small and temporary shock to social mobility. This tells us how a relatively small number of disaffected youth could have triggered a broad-based and long-lasting religious revival.

This paper is related to several lines of research in economics. The first wave of models in the economics of religion demonstrated that puzzling forms of religious behavior, including bizarre prohibitions and stigmatizing behavior, could be rationalized without resort to psychological explanations (see Iannaccone 1990, 1992, Berman 2000). This is not to say that psychological and cultural factors are irrelevant to religious behavior. Indeed, Iannaccone (1998) suggests that "religion would seem to be the ideal testing ground for models of value change and belief formation" [p. 1491]. This paper is part of a recent body of work that analyzes the formation and social transmission of religious beliefs and values (Bisin \& Verdier 2000, Iannaccone et al. 2011, Carvalho \& Koyama 2012, Carvalho 2013). It is also related to the economics of identity literature (Akerlof \& Kranton 2000, 2010, Austen-Smith \& Fryer 2005, Fang \& Loury 2005). Akerlof and Kranton (2000, 2010) argue that by choosing a new social identity, an individual adopts a different system of values. In this paper, we assume that a religious identity produces religious values which help individuals cope with economic loss.

There has been a recent flowering of research on the economics of Islam and Muslim societies, led by Kuran $(2004 b, a, c, 2010)$. Much of this work has focussed on how the economic development of the Middle East has been shaped by Islamic institutions (Kuran 2010, Chaney 2011, 2012, Blaydes \& Chaney forthcoming, Platteau 2008). There are relatively few studies that examine how religious belief and participation among Muslims is shaped by economic 
development. One notable exception is Chen (2010), who documents an increase in communal Quar'an study and Islamic school attendance in Indonesia following the 1997-98 financial crisis. Using variation in relative prices induced by the financial crisis, Chen finds that religious participation smooths household consumption and thus serves as a form of communal social insurance. In countries such as Egypt, Turkey, Lebanon and Jordan, religious organizations provide social services by drawing on volunteers from the educated middle class, e.g. doctors, lawyers, administrators (Clark 2004, Wickham 2002). We shall provide an explanation for this pattern of religious participation and show how the psychological function of religion can help to attenuate the free-rider problem in providing social services. In a related study of veiling among Muslim women, Carvalho (2013) demonstrates how a widespread rise in religiosity, combined with increased economic opportunities for women, can lead to an increase in religious identification among young, educated women.

The remainder of this paper is structured as follows: In section 2, we review existing survey, ethnographic and historical evidence on the Islamic revival. In section 3 we present quantitative evidence of a decline in social mobility among educated youth in Egypt. Section 4 develops a formal model of religion and shows how a decline in social mobility can give rise to a widespread religious revival. Various implications of the model are derived and discussed. Section 5 concludes.

\section{The Islamic Revival}

In this section, we provide a brief overview of existing survey, ethnographic and historical evidence. We make two points. Firstly, beginning some time during the 1970s and 1980s, Egypt witnessed a widespread Islamic revival - a rise in religious participation, values and identification. Secondly, it was educated youth from the lower socio-economic strata that were in the vanguard of this movement. The Egyptian movement (roughly) coincided with an Islamic resurgence in several other Muslim societies.

The chief obstacle to studying the Islamic revival in Egypt (or for that matter, anywhere) is the absence of time-series data on religiosity among Muslims over the second half of the twentieth century. This confines us, for the moment, to proposing a theory of the Islamic revival. Fortunately, there is a voluminous historical and anthropological literature on the resurgence in Islam (see for example the 111-page bibliography compiled by Esposito et al. 
(1991)), which we use to guide our theory. ${ }^{6}$ The remainder of this section is based on this literature. In section 3, we conduct our own empirical analysis of trends in education and social mobility in Egypt in order to further motivate our theory.

\subsection{A Broad-Based Islamic Revival in Egypt}

The Islamic revival in Egypt is apparent in many ways. There is a widely perceived increase in religious observance, including mosque attendance, prayer and fasting (Esposito 1999, p. 10). Islamic greetings and expressions (such as Mashallah- "whatever God wills") have come into more frequent use. Islamic books and journals (Wickham 2002, p. 101-2) and sermons recorded on cassette (Hirschkind 2006) have become increasingly popular. Carvalho (2013) reviews evidence of an increase in conspicuously Islamic dress. Beginning with the deveiling movement launched by Huda Shaarawi in Cairo in 1923, the practice of veiling among women - concealing the hair and face in particular - disappeared from sight. Yet by 2000, around 80 percent of Cairene women wore some form of headcovering (Bayat 2007). Many Egyptian singers, dancers and actresses left their professions, veiled and denounced their art as shameful (van Nieuwkerk 2007). ${ }^{7}$

Part of the increase in religious activity has been channeled through Islamic organizations. Social organizations which provide healthcare, education and financial aid, often centred around private mosques, have proliferated (see Wickham 2002, p. 99-102). In Egypt, Islamic organizations accounted for at least half of all welfare organizations in the late 1990s, with the number of beneficiaries of health services from such organizations rising from 4.5 million in 1980 to 15 million in 1992 (Bayat 2002, p. 12). The number of independent mosques in Egypt rose from 20,000 in 1970 to more than 46,000 in 1981 (Wickham 2002, p. 98). In 1970, university student unions in Cairo were the bastion of secular leftist intellectuals. By the end of the 1970s, Islamist student leaders controlled student unions in most faculties at Cairo University and other higher educational institutions.

The Muslim Brotherhood continues to be the chief Islamic political organization in Egypt.

\footnotetext{
${ }^{6}$ See also Hunter (1988), Esposito (1999), Lapidus (2002) and Bayat (2007).

${ }^{7}$ See Patel (2012) and Carvalho (2013) for theories of veiling. Counter to global trends, traditional values regarding women's rights and sexual mores appear to have generally strengthened in Muslim societies (e.g. Norris \& Inglehart 2004). Based on their analysis of World Values Survey data, Norris and Inglehart concludes that "the basic cultural fault line between the West and Islam does not concern democracy -it involves issues of gender equality and sexual liberalization" [p. 155].
} 
Formed by Hassan al-Banna in 1928 (see Mitchell 1993), the Muslim Brotherhood began to establish itself throughout the Middle East shortly thereafter. It was not until the 1970s, however, following defeat in the Six-day war and deepening economic crisis, that there was a popular Islamic social movement and widespread support for their program (Ayubi 1991, p. 59). By the early 1990s, the Muslim Brotherhood had gained control of many of Egypt's professional associations, including the engineers', doctors', pharmacists', scientists' and lawyers' associations (Wickham 2002, p. 2). In 2005, Muslim Brotherhood candidates won $20 \%$ of parliamentary seats, despite electoral irregularities and being banned from forming a political party. In the parliamentary elections following the 2011 revolution, the Muslim Brotherhood Freedom and Justice Party won $47 \%$ of vote. The Salafist Al-Nour Party won a surprisingly high $28 \%$ of vote. In June 2012, the Muslim Brotherhood candidate, Mohamed Morsi, was elected President of Egypt.

\subsection{Demographic Profiles}

As a first step toward understanding the factors behind the resurgent appeal of Islam in Egypt, we examine the demographic characteristics of active members of Islamic organizations. There is a consensus in the literature that active members, especially those who were in the vanguard of the Islamic movement in the 1970-80s, are typically young (early twenties); middle or lower-middle class (e.g. father in middle grade of civil service); university-educated, often in elite faculties (engineering, medicine), surpassing their parents' in terms of educational attainment; urban-based (e.g. peripheral suburbs of Cairo), recent migrants from rural areas or small towns; and have cohesive families, with no major life traumas. These key demographic characteristics were first documented by Ibrahim (1980) in his landmark study of two Egyptian militant groups - Shabab Muhammad and al-Takfir w'al-Hijra. For our purposes, it is important that this pattern of Islamic appeal has been confirmed for the broader Islamic movement in Egypt (Mitchell 1993, Wickham 2002, Bayat 2002), of which the militant groups are a fringe element. ${ }^{8}$ These characteristics also seem to match profiles

\footnotetext{
${ }^{8}$ Ibrahim (1980) claims that "[t]hese [militant] Islamic groups represent the small hard core of a broad but amorphous mass of religiosity in the society as a whole" [p. 425]. That moderate and militant Islamic activists share some key characteristics is not altogether surprising given the recruitment procedures employed by some militant groups: "Typically the older members would observe young worshippers in the college or neighborhood mosque. If the young persons appeared to be deeply religious (especially if they observed the dawn prayer), they would be approached to attend religious discussion after regular prayers. It was during these discussion that the potential member was discovered already to be or capable of becoming politically
} 
of activists in the broader Islamic movement in Jordan (Azem 1997), Tunisia (Waltz 1986, Hoffman 1995), Yemen (Clark 2004) and other Muslim societies (Ayubi 1991). We shall now document significant economic changes, which occurred in the lead up to the Islamic revival and affected precisely this section of Egyptian society.

\section{Declining Social Mobility and Returns to Education}

In this section, we present the first systematic empirical evidence of a decline in social mobility among the educated in Egypt during the late 1970s and 1980s. We do so by comparing social mobility among the educated and returns to education (in terms of occupational outcomes) before and after this time period (mid-1980s), during which major changes took place in the labor market.

After the 1952 Egyptian revolution, there was a big push to increase educational attainment, both at lower and higher levels of education. Between 1952-3 and 1976-7, higher education enrolments grew at an average rate of 32 percent per annum, and doubled in just four years after 1971 (Richards \& Waterbury 1996, p. 119). There was also a plan to provide employment for this new educated class. Egypt introduced a scheme guaranteeing public sector employment for secondary school and university graduates in the early 1960s. From $1962 / 63$ to $1969 / 70$, the number of posts in the public bureaucracy increased by 70 percent (compared to a 20 percent increase in the labour force) and average salaries increased by 128 percent (Ayubi 1989, p. 6). ${ }^{9,10}$ However, the scheme became increasingly untenable in the early 1980s, and has since the early 1990s been essentially defunct (Assaad 1997, 2007). As public sector job growth declined, the marginalized and highly regulated private sector

conscious" (Ibrahim 1980, p. 438). This suggests that religious commitment might be a necessary but not sufficient condition for recruitment to a militant religious organization. But we do not, in any way, equate religiosity with militancy. See for example the study on the positive effects of the Hajj, in terms of religious tolerance and attitudes toward women, by Clingingsmith, Khwaja \& Kremer (2009).

${ }^{9}$ Many Middle Eastern governments felt responsible for providing employment to those with intermediate or higher education who were unable to find a job in the private sector, partly out of fear of political unrest among urban youth (e.g. Mazumdar 1989, Salehi-Isfahani 2007). As a consequence, the public sector was, and still is, large in many Middle Eastern countries (Richards \& Waterbury 2008). A formal job guarantee scheme was also implemented in Morocco.

${ }^{10}$ The introduction of the employment guarantee scheme in Egypt was, in turn, associated with a strong increase in the demand for higher levels of education among the population, including those from the lower socio-economic strata (see also section 3.2). This contrasts with trends in educational attainment in developing countries outside the region (e.g. Jensen 2010, Barro \& Lee 2010). 
was incapable of absorbing the growing ranks of educated youth (more details on changes in the educational system and the labor market are provided in the Web Appendix). We study the effect of this series of changes in labor market conditions by comparing intergenerational occupational mobility for university graduates born in the 1950s (i.e. 1949-1960, "old cohort"), who benefited from the government guaranteed employment scheme, to those born in the 1970s (i.e. 1968-1977, "young cohort"), who generally did not. ${ }^{11}$

We use representative household survey data from Egypt, the Egypt Labor Market Panel Survey of 2006 (ERF, 2006). The empirical analysis is restricted throughout to males due to low female labor force participation in Egypt. ${ }^{12}$ Labor market outcomes are measured in terms of occupational status. This is appropriate to the Egyptian context. Due to the decline in real wages in the public sector in the 1980s, which was aimed at counterbalancing the high demand for public sector jobs, formal jobs in the Egyptian public sector can pay less than manual jobs in the informal sector. Nevertheless, public sector employment is preferred by graduates because it confers prestige, a more stable income stream and access to a wide range of goods and services (Assaad 1997). For wage workers, we additionally use information on job formality and the sector of employment.

Our results suggest the following. Firstly, there was an increase in educational attainment and educational mobility across cohorts. Secondly, the number of professional or white-collar jobs available, as a fraction of the educated labor force, declined, pushing more educated young people into low-skilled occupations in the informal sector. Thirdly, graduates whose fathers were not professionals were roughly 20 percentage points less likely to secure a professional occupation. In sum, there was an unequal decline in returns to education in Egypt during the 1970s-1990s, concentrated on graduates from low-socioeconomic backgrounds. We also present suggestive evidence that the increased labor market advantage of those from high-socioeconomic backgrounds was due to superior personal connections (wasta). In the interests of concision, only core results are presented here. Further empirical analyses, along with a more detailed description of changes in Egyptian educational and labor market

\footnotetext{
${ }^{11}$ The old cohort was also the first to benefit from free access to education (see Web Appendix).

${ }^{12}$ Over the past decades, female market labor force participation has slowly increased from $12 \%$ in 1986 (Richards 1992, p. 4) to slightly over 20\% in the 1990s and 27\% in 2006 (Assaad \& El Hamidi 2009). With jobs in the government sector declining, women - particularly the highly educated - faced increased difficulties obtaining jobs commensurate with their education (Assaad \& El Hamidi 2009). Gender segregation in the labor market remains high (World Bank 2004a) and many women stop working after marriage (e.g. Hoodfar 1997).
} 
institutions, are presented in the Web Appendix (for online publication only).

\subsection{Data and Measurement Issues}

The empirical analysis is based on data from the 2006 cross-section of the Egypt Labor Market Panel Survey (ELMPS06). 8,349 households (consisting of 37,140 individuals) were captured in this nationally representative survey in 2005-06. ${ }^{13}$ The old cohort (men born in 1949-1960) comprises 1,860 individuals, while the young cohort (men born in 1968-1977) comprises 2,650 individuals. The increase in the sample size reflects rapid population growth in Egypt.

Two features of the dataset are central to the empirical analysis. First, the ELMPS06 contains information about an individual's employment history. This allows dealing with the potential life-cycle bias in intergenerational economic mobility estimates (see e.g., Erikson et al. 1983, Nicoletti \& Ermisch 2007) by comparing job outcomes across cohorts at a given age. Second, the dataset provides education and job-related information about the respondent's parents also if parents are not present in the household. In the following, we provide more details on each. Summary statistics for both cohorts are presented in Table 1 in the Web Appendix.

The ELMPS06 contains information about an individual's first job, current job and up to two previous jobs. Employment-related information includes an individual's occupation, his wage status and, for wage workers, their sector of employment and whether they have a work contract and/or social insurance. Intensive data cleaning and consistency checks of the employment history section revealed that merely $4.13 \%$ of men aged $20-65(\mathrm{~N}=8,977)$ had held more than three jobs at the time of the survey. ${ }^{14}$ For another $2.48 \%$ of men in this age group, the employment history section of their completed questionnaire contains inconsistencies or errors, or it lacks information about the year an individual started an

\footnotetext{
${ }^{13}$ Among them, 3,684 households had been previously interviewed in the 1998 survey wave and 2,167 households represented splits from these. The remaining 2,498 households were new (refresher sample). Unless otherwise stated, descriptive statistics are based on the weighted data.

${ }^{14}$ We conduct a robustness analysis which shows that using information about men's current and first job in the event of missing data does not change results qualitatively (see Web Appendix). For a small number of men, whose earliest job in the employment history section started at most one year after they took up their first job, it is assumed that they did not experience any job change between their first job and the earliest job in the employment history section.
} 
activity and/or about his employment status. Thus, complete information is available for $93.39 \%$ of men aged 20 to 65 .

In the empirical analysis, we distinguish between professional and non-professional occupations. As part of the robustness analysis, we use five occupational categories, namely professional, white-collar, skilled manual workers, semi-/unskilled manual workers and farmers. ${ }^{15}$ For wage workers, we additionally examine whether the son holds a formal job, which is defined as providing both a work contract and social insurance, and whether he is working in the public or private sector. We compare, across cohorts, a son's occupational status at age 28. The choice of 28 as a reference age for sons is based on our expectation that most men in the two cohorts have reached their permanent occupational status, "occupational maturity" (Erikson et al. 1983), by that age. Evidence to this is provided in section 2 of the Web Appendix. It shows that men experienced relatively few job changes and if they did, it was usually at the beginning of their careers. If we consider only job changes that result in an occupational change, a high share of men had a maximum of two changes. On average, men were 28 when they experienced this second occupational change. ${ }^{16}$ Results are robust to comparing alternatively job and occupational outcomes of sons at age 30, in which case the young cohort comprises men born 1968-1975 (instead of 1968-1977). ${ }^{17}$

We relate the son's occupation to his father's occupational status when the son was aged 15. When the father was absent from the household, the interviewee was asked about his father's education, i.e. the highest degree obtained, as well as the father's occupation and sector of employment when the interviewee was 15. For sons living together with their fathers, this information was derived from the household questionnaire. ${ }^{18}$ Out of all sons with valid

\footnotetext{
${ }^{15}$ Details on the underlying occupational codes and on the construction of the five categories, including a list of the most numerous occupations within each category, are provided in the Web Appendix.

${ }^{16}$ At this age, $99 \%$ of men aged $20-65$ (with a valid job path) had obtained their first job. Only $12 \%$ of the male sample (aged 28-65) had experienced a longer unemployment phase by the time of the survey and less than $1 \%$ had experienced two phases. Similarly, "jobless" periods including temporarily disability and the residual category "other" have essentially occurred prior to age 28. Most of these men were unemployed early in life after leaving school and before obtaining their first job. This reflects the fact that in Egypt unemployment is essentially a school-to-work-transition problem (World Bank 2004b, Assaad 2009). Also, there are no (or little) social welfare benefits that can be claimed. Less than $10 \%$ of those who had experienced unemployment had been affected at age 28 or later and only a couple of individuals at age 28 . Consequently, not working does not constitute a category of its own. Instead, the occupation prior to the unemployment period is used for those who were unemployed at age 28 .

${ }^{17}$ The only difference is that coefficient estimates are slightly smaller in size. Results are reported in section 5 in the Web Appendix.

${ }^{18}$ The survey does not provide the age of fathers who are not living with their sons. However, when a son
} 
employment history information, the father's occupational status when the son was aged 15 and father's years of schooling were available in $98 \%$ of cases. Missing information was most often related to the fathers' occupation, i.e. to fathers who were living in the household at the time of the survey and who had missing entries in the employment history section. Less than $1 \%$ of fathers were recalled by interviewees as not working when the interviewee was 15. These fathers and sons were dropped from the empirical analysis.

\subsection{Increasing Educational Mobility}

Table 1 presents, for each cohort, the outflow percentages from father's highest degree to son's degree. ${ }^{19}$ The bottom row reveals an increase in educational attainment across the cohorts. The share of surveyed males with secondary and post-secondary education increased significantly from $39 \%$ in the old cohort to $63 \%$ in the young cohort. The marginal distributions also indicate a rise in educational mobility. For the lowest class of paternal income, measured by the father having obtained no formal degree, the distribution for the young cohort first-order stochastically dominates the distribution for the old cohort. Among the young cohort, $36 \%$ of men whose fathers had no formal degree achieved a secondary school degree and $18 \%$ achieved a post-secondary degree. Among the old cohort, the figures are $18 \%$ and $12 \%$ respectively. This constitutes a marked increase in educational mobility from the bottom which is most likely due to the abolishment of school fees and the expansion of the Egyptian schooling system in the 1950s and 1960s. On the other hand, university education seems to have remained rather exclusive, the most likely reason being policy changes in the 1980s that aimed to ease pressures on the public sector by reducing the supply of university graduates. ${ }^{20}$

is 15 , his father is typically in his 40 s or older, so we expect fathers to have reached occupational maturity at the time of comparison.

${ }^{19}$ The outflow percentages are calculated from the mobility table of each cohort, which are available from the Web Appendix.

${ }^{20}$ Further regression analysis of educational outcomes presented in the Web Appendix are consistent with increased access to secondary education and little, if any, change with regard to university education. 
Table 1: Outflow Percentages for Fathers' and Sons' Educational Attainment. 1949-1960 Cohort $(\mathrm{N}=1,858)$

\begin{tabular}{llrrrrr}
\hline \hline & & \multicolumn{5}{c}{ Son's education } \\
& & \multicolumn{1}{c}{$(1)$} & \multicolumn{1}{c}{$(2)$} & \multicolumn{1}{c}{$(3)$} & \multicolumn{1}{c}{ (4) } & Total \\
\hline \multirow{3}{*}{ Father's } & (1) No degree & 51.24 & 18.32 & 18.12 & 12.32 & 100.00 \\
education & (2) Primary/preparatory degree & 12.74 & 13.57 & 26.58 & 47.11 & 100.00 \\
& (3) Secondary degree & 4.72 & 6.58 & 29.14 & 59.56 & 100.00 \\
& (4) Post-secondary degree & 0.00 & 1.54 & 12.22 & 86.24 & 100.00 \\
\hline \multirow{2}{*}{ Total } & 44.07 & 16.79 & 19.09 & 20.05 & 100.00
\end{tabular}

1968-1977 Cohort $(\mathrm{N}=2,631)$

\begin{tabular}{llrrrrr}
\hline \hline & & \multicolumn{5}{c}{ Son's education } \\
& & \multicolumn{1}{c}{$(1)$} & \multicolumn{1}{c}{$(2)$} & \multicolumn{1}{c}{$(3)$} & \multicolumn{1}{c}{$(4)$} & Total \\
\hline \multirow{3}{*}{ Father's } & (1) No degree & 25.87 & 19.54 & 36.11 & 18.48 & 100.00 \\
education & (2) Primary/preparatory degree & 6.07 & 13.55 & 41.13 & 39.26 & 100.00 \\
& (3) Secondary degree & 0.93 & 4.68 & 38.59 & 55.80 & 100.00 \\
& (4) Post-secondary degree & 0.47 & 1.52 & 10.03 & 87.97 & 100.00 \\
\hline \multirow{2}{*}{ Total } & 20.20 & 16.62 & 35.09 & 28.10 & 100.00
\end{tabular}

Source: ELMPS06.

\subsection{Declining Occupational Mobility}

Table 2 reveals that rising educational mobility was not met by rising occupational mobility. $^{21}$ The marginal distributions indicate that the share of non-manual occupations has not changed over time. A decrease in the share of farmers has essentially been associated with an increase in the share of other manual occupations. The fact that professional, and, more generally, non-manual occupations have become relatively scarce is confirmed in Figure 1. Among men with secondary school degrees and above, 83\% (59\%) of the old cohort obtained a non-manual (professional) occupation by the age of 28 compared to $61 \%$ (41\%) of the young cohort. Among men with a university education, the decline is somewhat less drastic. Similarly, the share of formal jobs out of all wage work decreased: among secondary graduates and higher, $57 \%$ of the young cohort compared to $86 \%$ of the old cohort had a formal job by the age of 28 ; among university graduates, the comparable figures are $76 \%$ and 88\%. Public sector employment has become more scarce too: among university graduates,

\footnotetext{
${ }^{21}$ The corresponding mobility tables are available from the Web Appendix. They show in particular the strong decline in the share of farmers over the past century.
} 
Table 2: Outflow Percentages for Fathers' and Sons' Occupational Attainment. 1949-1960 Cohort $(\mathrm{N}=1,617)$

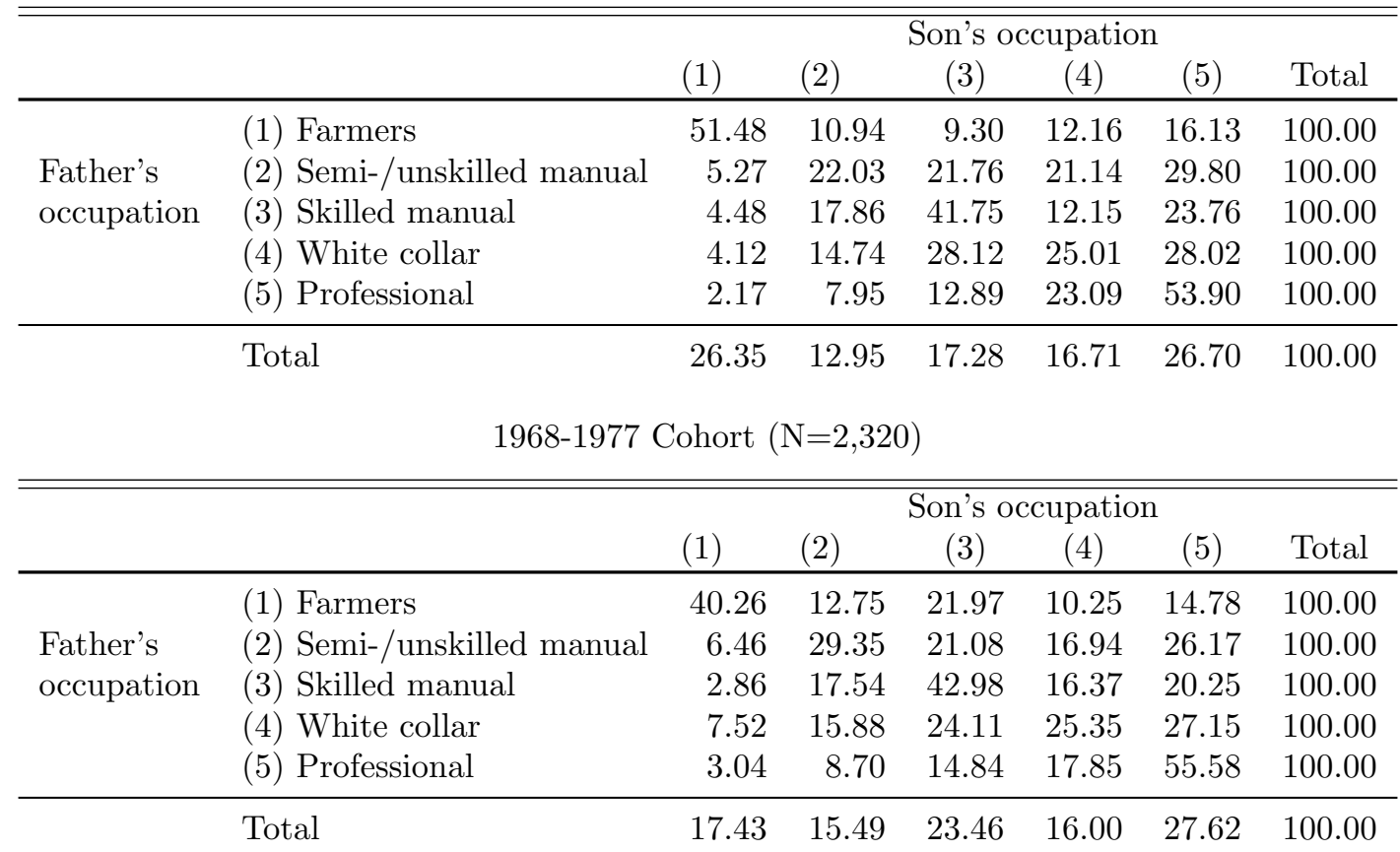

Notes: Son's occupation refers to his occupation at age 28. Source: ELMPS06.

only $58 \%$ of the young cohort worked in the government sector compared to $82 \%$ of the old cohort; for secondary school graduates and higher the figures are $43 \%$ and $80 \%$, respectively. The decline in government sector employment has been more dramatic than the decline in formal jobs which shows that the private sector is increasingly offering non-manual, formal jobs too, especially for university graduates.

Figure 2 in the Web Appendix plots for each cohort the educational distribution of workers across occupations. While the increase in educational attainment has raised the average amount of schooling within each occupation, there is also a strong increase in the share of men with a secondary degree who seem "stuck" in semi-/unskilled manual work. Based on the available ISCO codes in the survey, the most common occupations in this group are taxi driver and security guard (see Table 2 in the Web Appendix). In fact, secondary school graduates make up by far the largest educational group of all semi-/unskilled workers. While relatively few university graduates hold a manual occupation, their share has increased across cohorts as has their share among white-collar occupations. 


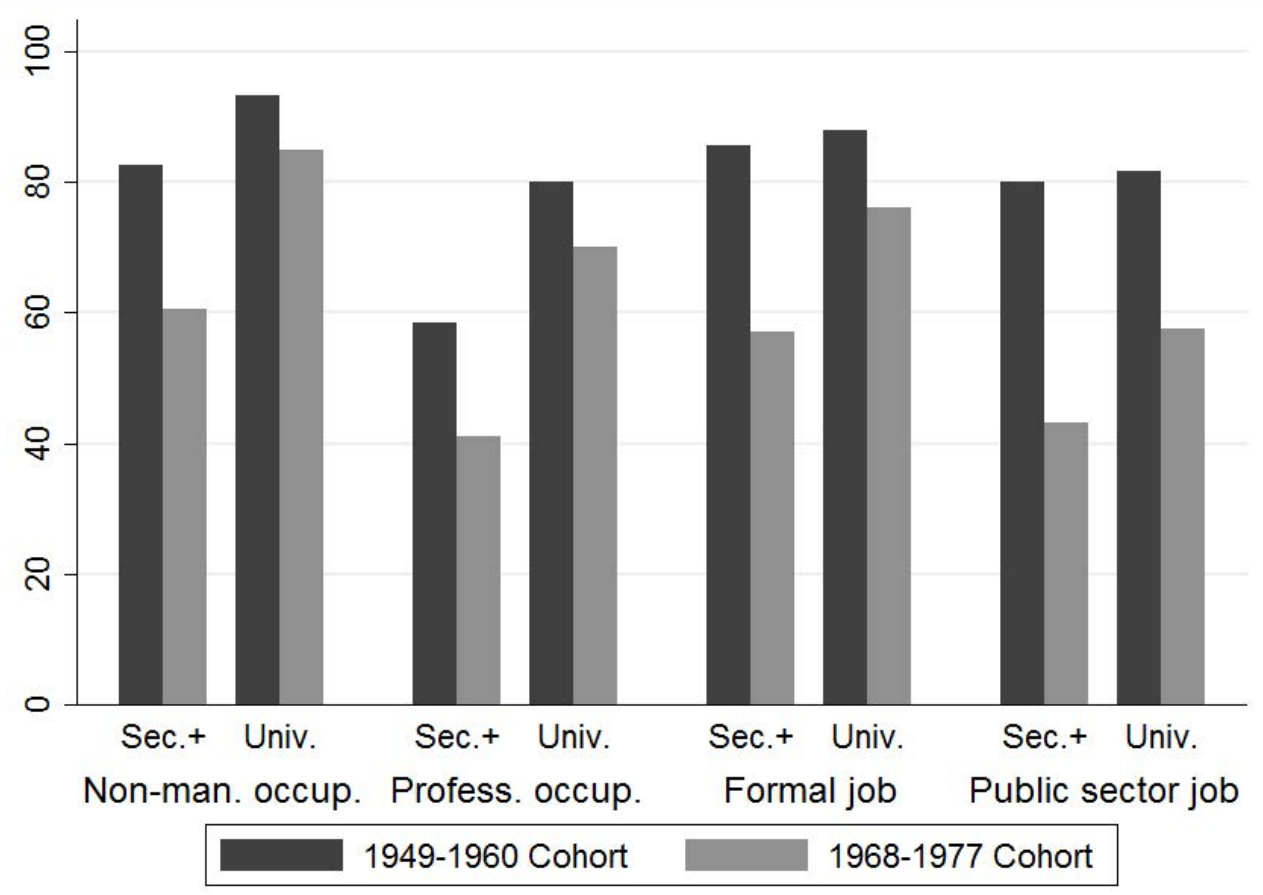

Figure 1: Changes in the Availability of Jobs across Cohorts.

Notes: This figure shows, separately for the old and the young cohort, the percentage of men with (i) secondary degrees and above ("Sec.+") and (ii) post-secondary (university) degrees ("Univ."), who had obtained a non-manual occupation (professional occupation / formal job / public sector job) by the age of 28. Source: ELMPS06.

Overall, the descriptive analysis suggests that changes in the Egyptian labor market did not "merely" affect the school-to-work transition but had a more permanent negative effect on the occupational outcomes of educated youth. We shall take a closer look at whether this effect was felt unequally by men from low socioeconomic backgrounds. For the sample of men of the old and the young cohort who achieved at least a university or a comparable degree (i.e. a post-secondary degree), we estimate the following basic regression model:

$$
P(\text { Prof }=1)=\alpha_{0}+\alpha_{1} \operatorname{Prof}^{f a}+\alpha_{2} Y n g+\alpha_{3} \operatorname{Prof}^{f a} \times Y n g+\alpha_{4} \text { Urban }+\nu
$$

where $P(\operatorname{Prof}=1)$ refers to the son's probability of obtaining a professional occupation or, more generally, a non-manual occupation, which includes white collar occupations, by the age of 28. $\alpha_{1}$ gives the correlation between father's and son's occupation, which can be interpreted as a measure of intergenerational occupational immobility, and $Y n g$ is a dummy for belonging to the young cohort (i.e. sons born in 1968-1977). The main coefficient 
Table 3: Relationship between Father's Occupation and Son's Occupation/Job (at Age $28)$.

\begin{tabular}{|c|c|c|c|c|}
\hline & $\begin{array}{l}\text { Dependent } \\
(1) \\
\text { non-manual } \\
\text { occupation }\end{array}$ & $\begin{array}{c}\text { variable: son' } \\
(2) \\
\text { professional } \\
\text { occupation }\end{array}$ & $\begin{array}{l}\text { probability } \\
\qquad(3) \\
\text { formal job }\end{array}$ & $\begin{array}{c}\text { obtain a } \\
(4) \\
\text { public } \\
\text { sector job }\end{array}$ \\
\hline \multicolumn{5}{|c|}{ a. Subsample of sons with post-secondary (university) degrees: } \\
\hline Young cohort $(\mathrm{d})$ & $\begin{array}{c}-0.125^{* * *} \\
(0.033)\end{array}$ & $\begin{array}{c}-0.179^{* * *} \\
(0.042)\end{array}$ & $\begin{array}{c}-0.209^{* * *} \\
(0.038)\end{array}$ & $\begin{array}{c}-0.252^{* * *} \\
(0.043)\end{array}$ \\
\hline Father: professional (d) & $\begin{array}{c}0.041 \\
(0.031)\end{array}$ & $\begin{array}{r}-0.003 \\
(0.049)\end{array}$ & $\begin{array}{r}-0.068 \\
(0.050)\end{array}$ & $\begin{array}{c}0.024 \\
(0.051)\end{array}$ \\
\hline $\begin{array}{l}\text { Father: professional } \\
\quad \times \text { young cohort }\end{array}$ & $\begin{array}{l}0.102^{* *} \\
(0.041)\end{array}$ & $\begin{array}{l}0.191^{* * *} \\
(0.061)\end{array}$ & $\begin{array}{l}0.238^{* * *} \\
(0.061)\end{array}$ & $\begin{array}{r}-0.012 \\
(0.070)\end{array}$ \\
\hline $\begin{array}{l}R^{2} \\
\mathrm{~N}\end{array}$ & $\begin{array}{c}0.046 \\
1,002\end{array}$ & $\begin{array}{c}0.039 \\
1,002\end{array}$ & $\begin{array}{c}0.053 \\
870\end{array}$ & $\begin{array}{c}0.085 \\
870\end{array}$ \\
\hline \multicolumn{5}{|c|}{ b. Subsample of sons with secondary degrees and above: } \\
\hline Young cohort $(\mathrm{d})$ & $\begin{array}{l}-0.255^{* * *} \\
(0.028)\end{array}$ & $\begin{array}{l}-0.201^{* * *} \\
(0.031)\end{array}$ & $\begin{array}{l}-0.335^{* * *} \\
(0.028)\end{array}$ & $\begin{array}{l}-0.388^{* * *} \\
(0.029)\end{array}$ \\
\hline Father: professional (d) & $\begin{array}{l}0.093^{* * *} \\
(0.032)\end{array}$ & $\begin{array}{l}0.148^{* * *} \\
(0.043)\end{array}$ & $\begin{array}{l}-0.057 \\
(0.040)\end{array}$ & $\begin{array}{c}0.002 \\
(0.041)\end{array}$ \\
\hline $\begin{array}{l}\text { Father: professional } \\
\quad \times \text { young cohort }\end{array}$ & $\begin{array}{l}0.174^{* * *} \\
(0.041)\end{array}$ & $\begin{array}{l}0.133^{* *} \\
(0.053)\end{array}$ & $\begin{array}{l}0.241^{* * *} \\
(0.052)\end{array}$ & $\begin{array}{c}0.055 \\
(0.055)\end{array}$ \\
\hline & 0.111 & 0.088 & 0.109 & 0.126 \\
\hline & 2,186 & 2,186 & 1,777 & 1,777 \\
\hline \multicolumn{5}{|c|}{$\begin{array}{l}{ }^{*} \mathrm{p}<0.10,{ }^{* *} \mathrm{p}<0.05,{ }^{* * *} \mathrm{p}<0.01 .(\mathrm{d}) \text { Dummy variable. } \\
\text { Notes: OLS coefficient estimates are reported with robust standard errors controlling } \\
\text { for clustering at the household level in parentheses. The analysis is restricted to men } \\
\text { (sons) born } 1949-60 \text { (old cohort) and to men born } 1968-77 \text { (young cohort). Non-manual } \\
\text { occupations comprise white collar and professional occupations. All specifications in- } \\
\text { clude a dummy for being born in an urban area and a constant. }\end{array}$} \\
\hline
\end{tabular}

of interest is $\alpha_{3}$, which assesses changes in economic mobility across cohorts (over time). Finally, Urban is a binary variable indicating urban residence at birth. For wage workers, we additionally examine the son's probability of holding a formal job and a public sector job by the age of 28 . As the employment guarantee scheme affected also secondary school graduates, we alternatively restrict the sample to graduates with secondary school degrees or higher.

The upper part of Table 3 shows regression results for equation (1). ${ }^{22}$ As hypothesized, for the old cohort, university graduates from low socioeconomic backgrounds were not dis-

\footnotetext{
${ }^{22}$ Estimating a probit instead of a linear probability model produces highly similar results (see Section 5 in the Web Appendix).
} 
advantaged. That is, once they achieved a university degree, they had an equal chance of obtaining a professional occupation as those whose fathers were professionals. However, this no longer holds true for university graduates from the young cohort: having a father working as a professional increases the son's likelihood of also becoming a professional by 19 percentage points, and it increases (among the sample of wage workers) his likelihood of obtaining a formal job by 24 percentage points. Hence, the decline in the likelihood of obtaining a professional occupation (or formal job) has concentrated among graduates from the lower ranks. $^{23}$

The lower part of Table 3 shows that for the sample of secondary school graduates and above, a similar decline in social mobility is found as that for university graduates except that occupational outcomes were already less equal for the old cohort (columns (1) and (2)). Having a father working as a professional was associated with an increase in the son's likelihood of obtaining a professional occupation by 0.15 ; this is even more pronounced for the young cohort (an additional increase in the likelihood by 0.13). Regarding formal employment, however, the coefficient estimates are similar to those found for university graduates, in terms of both statistical significance and size. That is, parental background plays a role in obtaining a formal job only for the young cohort. Recall from Figure 1 that, for the old cohort, the share of graduates with secondary school degrees and above that had attained a professional occupation by the age of 28 was approximately 20 percentage points smaller than the corresponding share of university graduates ( $59 \%$ versus $80 \%$ ). This gap is negligible with regard to the share of educated youth with a formal job (around $85 \%$ for both subsamples). It thus seems plausible that, already for the old cohort, parental background mattered with respect to attaining a professional occupation, but not with respect to holding a formal job. That is, overall these results suggest that as soon as employment opportunities in the private sector become limited, graduates from a high socio-economic background have an advantage over those from a low socio-economic background.

The results in column (4) of Table 3 indicate that the decline in mobility is associated with the way jobs are allocated in the formal private, rather than in the public sector. For obtaining a job in the government sector, there is on average no advantage in having a father who is a professional. This is consistent with individuals from low socioeconomic backgrounds lacking the right skills (e.g. English language skills) and/or personal connections to obtain

\footnotetext{
${ }^{23}$ We show in the Web Appendix that these results are robust to various alternative specifications.
} 
a professional position in the private sector. One likely contributing factor to both sources of disadvantage would be the introduction of the infitah (open-door) policy in 1973 by the Egyptian government, which encouraged private sector growth and foreign direct investment in particular. While the dataset does not allow one to discriminate between the two sources of disadvantage, it does provide information about the main and the secondary (if there was a secondary) job search method used to obtain an individual's current primary job. Close to $40 \%$ of graduates working in the private sector received help from their family or friends in obtaining their job, compared to around $10 \%$ of graduates working in the public sector. ${ }^{24}$ If personal or social connections are based on kinship ties, this suggests that the increase in economic persistence across generations may be related, at least in part, to the increased importance of the personal connections, called "wasta", in obtaining professional positions.

\subsection{Unequal Decline in Returns to Education}

We shall now focus on returns to education in Egypt (in terms of occupational outcomes). ${ }^{25}$ Estimation results in column (1) in Table 4 show that, conditional on one's father not working in a professional occupation, (occupational) returns to education have declined over time: the likelihood of obtaining a professional occupation has declined by 15 percentage points for secondary school graduates and by 16 percentage points for university graduates. In contrast, results in column (2) indicate that for those whose fathers work as professionals, returns to university education have remained unchanged or increased slightly. Column (3) uses the full sample and confirms the unequal decline in returns to education in Egypt: for university graduates of the old cohort, the (occupational) returns to education were roughly the same (i.e. independent from their parental background) while for university graduates of the young cohort, those whose fathers were not working as a professional experienced a decline in the returns to education.

\subsection{Summary}

The remainder of the paper is devoted to modeling how an unequal decline in returns to education could lead to widespread religious revival. Prior to this analysis, let us write

\footnotetext{
${ }^{24}$ See also Figure 3 in the Web Appendix.

${ }^{25}$ In the following, we include all men in the analysis, irrespective of their educational attainment.
} 
Table 4: Changes in the Occupational Returns to Schooling over Time.

\begin{tabular}{|c|c|c|c|}
\hline & $\begin{array}{c}\text { Dependent } \\
\text { to obtain a } \\
(1) \\
\text { Father: } \\
\text { non-professional }\end{array}$ & $\begin{array}{c}\text { ariable: son's } \\
\text { ofessional occ } \\
(2) \\
\text { Father: } \\
\text { professional }\end{array}$ & $\begin{array}{l}\text { obability } \\
\text { ation }(\mathrm{d}) \\
(3) \\
\text { Full sample }\end{array}$ \\
\hline Primary/preparatory degree & $\begin{array}{c}0.013 \\
(0.020)\end{array}$ & $\begin{array}{r}-0.048 \\
(0.093)\end{array}$ & $\begin{array}{c}0.009 \\
(0.020)\end{array}$ \\
\hline Secondary degree & $\begin{array}{l}0.269^{* * *} \\
(0.033)\end{array}$ & $\begin{array}{l}0.231^{* *} \\
(0.092)\end{array}$ & $\begin{array}{l}0.266^{* * *} \\
(0.033)\end{array}$ \\
\hline Post-secondary degree & $\begin{array}{l}0.752^{* * *} \\
(0.033)\end{array}$ & $\begin{array}{l}0.505^{* * *} \\
(0.072)\end{array}$ & $\begin{array}{l}0.749^{* * *} \\
(0.033)\end{array}$ \\
\hline Young cohort $(\mathrm{d})$ & $\begin{array}{c}-0.011 \\
(0.012)\end{array}$ & $\begin{array}{r}-0.144^{*} \\
(0.080)\end{array}$ & $\begin{array}{r}-0.024^{*} \\
(0.013)\end{array}$ \\
\hline $\begin{array}{l}\text { Primary/preparatory degree } \\
\times \text { young cohort }\end{array}$ & $\begin{array}{c}-0.013 \\
(0.024)\end{array}$ & $\begin{array}{c}0.189 \\
(0.130)\end{array}$ & $\begin{array}{r}-0.001 \\
(0.024)\end{array}$ \\
\hline $\begin{array}{l}\text { Secondary degree } \\
\quad \times \text { young cohort }\end{array}$ & $\begin{array}{l}-0.153^{* * *} \\
(0.037)\end{array}$ & $\begin{array}{r}-0.047 \\
(0.112)\end{array}$ & $\begin{array}{l}-0.141^{* * *} \\
(0.038)\end{array}$ \\
\hline $\begin{array}{l}\text { Post-secondary degree } \\
\quad \times \text { young cohort }\end{array}$ & $\begin{array}{l}-0.163^{* * *} \\
(0.044)\end{array}$ & $\begin{array}{r}0.160^{*} \\
(0.091)\end{array}$ & $\begin{array}{l}-0.152^{* * *} \\
(0.044)\end{array}$ \\
\hline Father: professional (d) & & & $\begin{array}{l}0.185^{* * *} \\
(0.043)\end{array}$ \\
\hline $\begin{array}{l}\text { Primary/preparatory degree } \\
\times \text { Father: professional }\end{array}$ & & & $\begin{array}{r}-0.011 \\
(0.083)\end{array}$ \\
\hline $\begin{array}{l}\text { Secondary degree } \\
\times \text { Father: professional }\end{array}$ & & & $\begin{array}{c}0.005 \\
(0.085)\end{array}$ \\
\hline $\begin{array}{l}\text { Post-secondary degree } \\
\quad \times \text { Father: professional }\end{array}$ & & & $\begin{array}{l}-0.206^{* * *} \\
(0.064)\end{array}$ \\
\hline $\begin{array}{l}\text { Primary/preparatory degree } \\
\times \text { Father: professional } \times \text { young cohort }\end{array}$ & & & $\begin{array}{c}0.064 \\
(0.106)\end{array}$ \\
\hline $\begin{array}{l}\text { Secondary degree } \\
\quad \times \text { Father: professional } \times \text { young cohort }\end{array}$ & & & $\begin{array}{r}-0.022 \\
(0.086)\end{array}$ \\
\hline $\begin{array}{l}\text { Post-secondary degree } \\
\quad \times \text { Father: professional } \times \text { young cohort }\end{array}$ & & & $\begin{array}{l}0.195^{* * *} \\
(0.062)\end{array}$ \\
\hline$R^{2}$ & 0.370 & 0.261 & 0.402 \\
\hline $\mathrm{N}$ & 3,154 & 855 & 4,009 \\
\hline
\end{tabular}

down several implications of our findings hitherto for understanding inequality in developing countries. Firstly, the theoretical literature on the transmission of income and wealth inequality across generations tends to implicate credit market imperfections, which constrain 
low-income families from investing in human capital (e.g. Loury 1981, Becker \& Tomes 1986, Mookherjee \& Ray 2002). This is a particular problem in developing countries, which face imperfections in other markets as well (e.g. Rosenzweig \& Wolpin 1993, Udry 1995) and are vulnerable to risks from a variety of sources, such as illness and drought (e.g. Morduch 1995). This reasoning has led some researchers to use intergenerational educational mobility estimates as proxies for economic mobility across generations, since earnings and occupational data regarding parents are often unavailable from surveys conducted in developing countries or the data do not allow one to control for potential life-cycle effects (e.g. Binder \& Woodruff 2002, Hertz et al. 2007, Louw et al. 2007, Hertz et al. 2009). ${ }^{26}$ As the empirical results of this paper illustrate, while increased access to education may be a necessary condition for increased economic mobility across generations, it is not a sufficient one.

Secondly, this paper makes a contribution to the resurgent debate about why programs that expand access to education have not been more effective in promoting economic growth in developing countries (Pritchett 2001, Hanushek \& Woessmann 2007). One response among scholars has been to shift attention from years of schooling to a closer examination of school quality and cognitive skills. The findings of this paper suggest a potential additional impediment to growth: the functioning of the labor market. In Egypt-and presumably the broader Middle East (compare World Bank 2004b) - the dominance of the public sector and the high degree of regulation in the private sector have constrained the labor market's ability to efficiently absorb skilled entrants. As we shall now argue, this can have dramatic social consequences.

\section{A Theory of the Islamic Revival}

\subsection{The Model}

Consider a society composed of a continuum of agents $I$ with typical member $i$. The set of agents is endowed with Lebesgue (uniform) measure $\lambda$. Agents (or their parents) choose their level of education and subsequently enter either the low class $L$ or high class $H$. Agents who end up in the $L$ and $H$ classes are subject to known wage rates $w_{L}$ and $w_{H}$ respectively,

\footnotetext{
${ }^{26}$ Among the few studies that use earnings or occupational data from developing countries are Valero-Gil \& Tijerina-Guajardo (2002) on Mexico, Grawe (2004) on Ecuador, Nepal, Pakistan, and Peru, Dunn (2007) on Brazil, and Ng (2007) on Malaysia.
} 
where naturally $w_{H}>w_{L}>0$. Once an agent's class status is realized, he divides his time between work and religious activity. The major departure of our model is that religious participation acts not only as a form of leisure (or social interaction), but also performs a psychological function in helping agents adjust to unfulfilled aspirations.

The precise structure of the game is as follows:

Date 0. Each agent starts out in one of two classes, the low class $L$ or the high class $H$. [One can interpret membership of the high class as having a father with a professional occupation, but the model will be more general.]

Date 1. Agents each choose a level of education $e \in[0,1]$. The cost of education is $k\left(e, a_{i}\right)$, where $a_{i}$ is a shift parameter which we shall interpret later. We assume that $k\left(0, a_{i}\right)=$ $k_{1}\left(0, a_{i}\right)=0$ and $k_{1}\left(e, a_{i}\right) \rightarrow \infty$ as $e \rightarrow 1$ for all $a_{i}$. In addition, we impose the SpenceMirrlees condition: $k_{12}\left(e, a_{i}\right)<0$ for all $a_{i}$.

Date 2. Agents are assigned to either the low or high class, $c_{i}=L, H$, based on their education and initial class status. Denote the set of agents who are assigned to class $c$ by $I_{c}$. The probability that $i \in I_{H}$ is $\mu_{i} \equiv \theta e_{i}+(1-\theta) B_{i}$, where $B_{i}$ is an indicator variable which equals one if $i$ started out in the $H$ class and zero otherwise and $\theta \in(0,1)$ is the degree of social mobility. This is essentially the same reduced-form representation of the labor market used by Piketty (1995) and Bénabou \& Tirole (2006). The higher is $\theta$, the more education matters relative to parental status. For the moment, we assume that $\theta$ is known.

Date 3. After observing his class status and corresponding wage, each agent has one unit of time to divide between work and religious activity (e.g. prayer, communal worship, religious education, volunteer work). Labor supply is denoted by $\ell_{i}$ and religious activity by $r_{i}$. We assume that the price of religious activity is zero, so that agents spend their entire income on a composite consumption good. ${ }^{27}$ The price of this composite good is normalized to one. Final payoffs, consisting of three components, are then received.

Firstly, agents receive utility from consumption. We assume that consuming $g$ units of the composite good yields utility of $\ln (g) .{ }^{28}$ Secondly, religion is, in part, a form of leisure in our model. An individual receives utility from religious participation $r$ of $F(r)$, where $F^{\prime}(r)>0$

\footnotetext{
${ }^{27}$ Berman (2000) makes the same assumption in a club goods model of religion.

${ }^{28}$ Hence income and substitution effects of wage changes on consumption perfectly offset each other. Only the results in Section 4.4 will depend in any meaningful way on this assumption.
} 
and $F^{\prime \prime}(r)<0$ for all $r \in[0,1], F^{\prime}(r) \rightarrow \infty$ as $r \rightarrow 0$.

The third component of payoffs depends on a reference point. This is the main departure of our model. Each agent compares his income $y_{i}=w_{c_{i}} \ell_{i}$, which is also the number of units of the composite good that he consumes, to his reference point (or target income) $Y_{i}$. This in turn will be determined endogenously (in a manner to be specified below) as part of the equilibrium distribution of income in society. In particular, a representative agent $i$ faces the following reference-dependent loss function:

$$
\left(1-r_{i}\right)^{\delta}\left(Y_{i}-y_{i}\right)_{+}^{1+\gamma}
$$

where $\gamma>0,{ }^{29} \delta \geq 0, Y_{i}-y_{i}$ is the gap between target income and actual income, and $\left(Y_{i}-y_{i}\right)_{+} \equiv \max \left\{Y_{i}-y_{i}, 0\right\}$ so that agents are only concerned with negative comparisons. ${ }^{30}$ (Both $\gamma$ and $\delta$ are interpreted in Section 4.2.2.) That is, an agent's reference-dependent utility is decreasing in the gap between his target income and actual income (when the gap is positive). However, the more an agent devotes himself to religious activity, the less he cares about falling short of his reference point, i.e. the coefficient $\left(1-r_{i}\right)^{\delta}$ is lower. Religious activity thus produces religious values that deemphasize failure to exceed one's reference point and/or adjusts one's reference point downward. We call this the psychological function of religion. This conception of religion as part of 'the psychological immune system' (Bénabou \& Tirole 2002) has a long history ${ }^{31}$ and is consistent with empirical evidence that religious beliefs and participation enhance self-esteem, life satisfaction and a person's ability to withstand traumatic experiences (see Ellison 1993, Smith et al. 2003). For example, Dehejia et al. (2007) find that weekly religious attendance by African Americans fully offsets the impact of income declines on happiness.

\footnotetext{
${ }^{29}$ The assumption that $\gamma>0$ makes our formulation consistent with Clark and Oswald's concavecomparison utility (Clark \& Oswald 1998).

${ }^{30}$ Shalev (2000) makes the same assumption that the reference point only enters an agent's utility function when outcomes fall below the reference point.

${ }^{31}$ Marx's claim that religion is "the opium of the people" is its most famous statement. Bainbridge's (1997) account of the formation of new religious sects among the poorer classes in Gaston county, North Carolina in the 1920s accords with this view. He quotes Liston Pope's theory that "an otherworldly emphasis in the newer sects affords compensation for poverty and transcendence of poor estate," adding that "[l]acking any of the symbols of happiness in the secular community, such as fine clothing and jewelry, they rejected those trifles in favor of the divinely conferred status of being sanctified or reborn in the Holy Spirit" (Bainbridge 1997, p. 34). In his classic work on religious experience, William James (1890/1974) also makes the distinction between material and religious values: "We have lost the power even of imagining what the ancient idealization of poverty could have meant: the liberation from material attachments, the unbribed soul, the manlier indifference, the paying our way by what we are or do and not by what we have... it is time for thinking men to protest against so unmanly and irreligious a state of opinion" [p. 356-7].
} 
Therefore, at date 3 , a representative agent $i \in I_{c}$ solves the following problem:

$$
\begin{gathered}
\max _{(\ell, r, g)} U_{i c}=\max _{(\ell, r, g)} \ln (g)+F(r)-(1-r)^{\delta}\left(Y_{i}-w_{c} \ell\right)_{+}^{1+\gamma} \\
\text { s.t. } \quad \ell+r \leq 1 \\
\quad g \leq w_{c} \ell,
\end{gathered}
$$

Since the objective function is strictly increasing in $\ell, r$ and $g$, both constraints bind in equilibrium for all agents. Substituting the goods budget constraint and the time budget constraint into the objective function, (3) reduces to an unconstrained optimization problem with a single choice variable $\ell$, or equivalently $r=1-\ell$. We can then write the utility function as $U_{i c}(r)$ for agent $i \in I_{c}$. We assume that the game is common knowledge and restrict our attention to pure strategies throughout.

\subsection{Unfulfilled Aspirations \& Religion}

Let us proceed via backward induction. We begin by analyzing the subgame commencing at date 2 , in which agents choose their labour supply $\ell$ and religious activity $r$ once their level of education has been chosen. This subgame will be referred to as the religion game. Hence, for the time being, the probability that each agent enters the $H$ class, $\mu_{i}=\theta e_{i}+(1-\theta) B_{i}$, is treated as fixed. We solve the religion game for an exogenous profile of education choices $\mathbf{e} \equiv\left(e_{i}\right)_{i \in I}$ at date 1 . We shall then turn our attention to equilibrium education choice in Section 4.3.

We now have a choice to make regarding the appropriate reference point $Y_{i}$ to which an agent compares his outcome at the end of the game. We relate the reference point to an income/consumption aspiration level, which depends in turn on an agent's expectations. Before learning the class to which he will finally be assigned, each agent $i$ forms an expectation of his income. His strategy specifies a religious participation choice $r_{i c}$ for each class $c \in\{L, H\}$. His equilibrium income in class $c$ will be $y_{i c}=w_{c}\left(1-r_{i c}\right)$. Hence $i$ 's expected income is $\mu_{i} y_{i H}+\left(1-\mu_{i}\right) y_{i L}$. This means that an agent who, when choosing education at date 1, expects a higher probability of ending up in the $H$ class will have a higher aspiration

level $Y_{i}$. In tying reference points to expectations, we follow Shalev (2000), Köszegi \& Rabin 
(2006) and Crawford \& Meng (2011). ${ }^{32}$

We rely upon the following solution concept, which is based upon the notion of personal equilibrium introduced by Köszegi \& Rabin (2006):

Definition 1. Fix a profile of education choices $\mathbf{e} \equiv\left(e_{i}\right)_{i \in I}$. A personal equilibrium [PE] of the religion game consists of (1) an aspiration level $Y_{i}$ and (2) a pair of religious participation choices $r_{i}=\left(r_{i L}, r_{i H}\right)$ for each agent $i \in I$ such that for all $i \in I$ and $c \in\{L, H\}$ :

(i) Treating $Y_{i}$ as fixed, $r_{i c} \in \operatorname{argmax}_{r \in[0,1]} U_{i c}(r)$,

(ii) $Y_{i}=\mu_{i} y_{i H}+\left(1-\mu_{i}\right) y_{i L}$,

(iii) $y_{i H}>y_{i L}$.

The first condition requires that for fixed aspiration levels $\left(Y_{i}\right)_{i \in I}$, religious participation choices maximize utility for each player. The second condition relates aspirations levels to income/consumption expectations and requires expectations to be consistent with equilibrium play. The third condition restricts attention to (plausible) equilibria in which an agent expects to earn more in the high-wage class than in the low-wage class. As such, only $L$ class members experience unfulfilled aspirations.

Agents are ex ante identical except for their initial class status. Ex post, initial class status only affects religious participation choice via its effect on unfulfilled aspirations. Members of the $H$ class do not experience unfulfilled aspirations. Hence they choose a common action, $r_{i H}=r_{H}$ for all $i \in I$. Members of the $L$ class do experience unfulfilled aspirations, and to varying degrees based on their education and initial class status. We can now state the following result:

Proposition 1 For every profile of education choices $\boldsymbol{e} \equiv\left(e_{i}\right)_{i \in I}$, there exists at least one personal equilibrium [PE] of the religion game. All religious participation choices are interior: $0<r_{i c}<1$ in every equilibrium for all $i \in I$ and $c \in\{L, H\}$.

\footnotetext{
${ }^{32}$ It will be clear that a formulation in which the reference point $Y_{i}$ equals the income of the high class (one could call this an 'envy formulation') has essentially the same mathematical structure. The only difference is that the equilibrium religious participation in the unfulfilled aspirations formulation also depends on agents' expectations of upward social mobility, $\mu_{i}$, and hence their level of education.
} 
The proof is in the appendix.

\subsubsection{Living up to Expectations}

We shall now study equilibrium religious participation by agents who end up in the low class $L$. We are interested in the role of factors that determine their degree of unfulfilled aspirations: inequality $y_{H}-y_{i L}$, social mobility $\theta$ and the individual's level of education $e_{i}$. The relative deprivation literature - Wickham (2002) being the outstanding example on Islam - predicts that higher inequality and expectations of upward mobility unconditionally lead to increased participation in religious movements, by those who fail to meet their aspirations. However, this neglects the possibility that individuals who fall short of expectations may work harder to live up to their expectations, and thus spend less time on religious participation.

To make this point formally, let us abstract from the coping effect of religion by setting $\delta=0 .{ }^{33}$ In this case, religion does not perform a psychological function in helping individuals to cope with unfulfilled aspirations. This version of the model is merely a neoclassical model of labor supply (where religion plays the role of leisure) combined with a concern for unfulfilled aspirations.

This produces the following comparative statics results:

Proposition 2 Fix a profile of education choices such that $0<\mu_{i}<1$ for all $i \in I^{34}$ Consider the religion game when religion performs no psychological function $(\delta=0)$. In every PE, religious participation choices for agents who end up in the L class are:

(i) strictly increasing in the equilibrium income of $H$ class members $y_{H}$,

(ii) strictly increasing (resp. decreasing) in social mobility $\theta$ for agents who start out in the $L$ (resp. H) class,

(iii) strictly increasing in the individual's level of education $e_{i}$.

\footnotetext{
${ }^{33}$ In this case, the utility function is similar to a parameterized version of the one used by Bowles \& Park (2005), except that the reference point used by Bowles and Park is $y_{H}$, the income $H$ class members.

${ }^{34}$ According to Proposition $4,0<\mu_{i}<1$ for all $i \in I$ in every equilibrium.
} 
The results follow from differentiation of (3) with respect to $r$, holding $Y_{i}$ fixed, then imposing $Y_{i}=\mu_{i} y_{i H}+\left(1-\mu_{i}\right) y_{i L}$ and finally differentiating the resulting expression with respect to the parameter of interest. There is one difference between agents who start out in the $L$ class and those who start out in the $H$ class. Higher social mobility means a greater likelihood that agents who start out in the $H$ class end up in the $L$ class. Hence an increase in $\theta$ reduces unfulfilled aspirations for agents who start out in the $H$ class. The opposite holds for agents who start out in the $L$ class. ${ }^{35}$ For all agents who end up in the $L$ class it is true that as unfulfilled aspirations rise - as a result of changes in inequality determined by $y_{H}$, social mobility $\theta$ or education $e_{i}$ - they strive to live up to their expectations by working harder and devoting less time, not more, to religious activity. Due to this living-up-to-expectations [LUE] effect, it is not obvious that a concern for unfulfilled aspirations is sufficient to explain a rise in religious activity. Something else is required.

\subsubsection{Coping with Unfulfilled Aspirations}

The remainder of the analysis will examine the case in which $\delta>0$. In this case, religion is not only a form of leisure, but also performs a psychological function in helping individuals to cope with unfulfilled aspirations. First differentiate (3) with respect to $r$, holding $Y_{i}$ fixed. Then impose $Y_{i}=\mu_{i} y_{i H}+\left(1-\mu_{i}\right) y_{i L}$. Finally, differentiate the resulting expression with respect to $y_{H}$ to get:

$$
\underbrace{(1+\gamma) \delta\left(1-r_{i L}\right)^{\delta-1} \mu_{i}^{1+\gamma}\left(y_{H}-y_{i L}\right)^{\gamma}}_{\text {coping effect }}-\underbrace{\gamma(1+\gamma) w_{L}\left(1-r_{i L}\right)^{\delta} \mu_{i}^{\gamma}\left(y_{H}-y_{i L}\right)^{\gamma-1}}_{\text {LUE effect }} .
$$

The coping effect dominates the LUE effect if and only if:

$$
y_{H}-y_{i L}>\frac{\gamma}{\delta} \frac{y_{i L}}{\mu_{i}}
$$

In other words, income inequality $y_{H}-y_{i L}$ must be sufficiently large for an increase in income inequality to produce a rise in religious participation among the $L$ class. The threshold level

\footnotetext{
${ }^{35}$ Recall that the likelihood of ending up in the $H$ class is $\mu_{i}=\theta e_{i}+(1-\theta) B_{i}$, where $B_{i}=1$ if $i$ started out in the $H$ class and zero otherwise. This means that $\mu_{i}$ is strictly increasing in $\theta$ if $i$ started out in the $L$ class and strictly decreasing in $\theta$ otherwise.
} 
of inequality for agent $i$ depends on the curvature of reference-dependent utility determined by $\gamma$ and $\delta$, his probability of upward mobility $\mu_{i}$ and $L$ class income $y_{i L}$.

A few remarks are in order. The parameter $\delta$ measures the intensity of the coping effect: the rate at which religious activity generates religious values. The parameter $\gamma$ measures the intensity of the (countervailing) LUE effect in which $L$ class agents work harder in order to live up to their expectations. Hence a larger ratio $\gamma / \delta$ implies that a higher level of income inequality is required for the coping effect to dominate. Notice also that as an agent's likelihood of upward social mobility falls to zero, the level of income inequality required for the coping effect to dominate becomes arbitrarily large. This has some intuitive appeal. While the medieval serf is at a great disadvantage relative to his lord, his inequality may be less acutely felt, because the serf cannot reasonably expect to become the lord. This suggests that economic development - in particular a rise in social mobility $\theta$ - could render economic inequality a more important determinant of behavior. As de Tocqueville (1856/1986) wrote of the French revolution, "the French found their position all the more intolerable as it became better." Thus, income inequality, social mobility and poverty are not separate but intimately related factors associated with religiosity among the $L$ class.

The same logic applies to $\theta$ and $e_{i}$. Hence, we have the following local comparative statics results:

Proposition 3 Fix a profile of education choices such that $0<\mu_{i}\left(e_{i}\right)<1$ for all $i \in I$. Consider the religion game when religion performs a psychological function $(\delta>0)$. In every PE, religious participation choices for agents who end up in the L class are locally:

(i) strictly increasing in the equilibrium income of $H$ class members $y_{H}$,

(ii) strictly increasing (resp. decreasing) in social mobility $\theta$ for agents who start out in the $L$ (resp. H) class,

(iii) strictly increasing in the individual's level of education $e_{i}$.

if and only if:

$$
y_{H}-y_{i L}>\frac{\gamma}{\delta} \frac{y_{i L}}{\mu_{i}} .
$$


The literature on relative deprivation posits a monotonic relationship between income inequality (and other measures of unfulfilled aspirations) and the incidence of social movements, including religious movements. Developing a model of religion with reference-dependent preferences and endogenous religious values, we find that the effect of changes in inequality, social mobility and education depends crucially on their levels. Our analysis cautions against imposing a simple linear relationship between religious participation and economic variables such as inequality in future empirical work.

Reference-dependent preferences also lead to a higher variance across countries in levels of (within-country) income inequality. Because a marginal increase in income inequality causes $L$-class agents to work harder when income inequality is low, this further compresses the income distribution relative to the distribution which prevails in the absence of referencedependent preferences. Conversely, when income inequality is high, a marginal increase in inequality causes $L$ class agents to devote less time to work. This makes the income distribution more dispersed. This suggests that rising within-country inequality, as has been observed among OECD countries (e.g. Atkinson 2003), could lead to both secularization in low-inequality countries (such as Japan, Sweden and Denmark) and a rise in religiosity in high-inequality countries (such as the United States and Ireland).

Finally, we can offer an explanation for why university graduates from elite faculties, who came from the lower socio-economic strata, have been among the most active agents of the contemporary Islamic revival. The higher is an individual's level of education, the higher is his expectation of upward mobility and the greater the disappointment he faces when stuck in the $L$ class. This is not, however, sufficient to induce an agent to increase religious participation in our model. An educated agent's response to unfulfilled aspirations is crucially intermediated by the level of income inequality. Indeed there is some evidence of a rise in income inequality in Egypt over this period due to trade liberalization and public sector cuts.

During the 1970s oil-price boom and trade liberalization (Sadat's open-door policy), privatesector professionals benefitted from lucrative jobs in the petroleum, banking and construction industries. Wickham (2002, p. 52-3) estimates that entry-level positions for graduates in joint ventures and foreign firms paid a staggering twelve times more than those in local government administration, and around four times more than those in elite government departments such as the Ministries of Justice, Finance and Petroleum. The economic crisis of 
the 1980s also saw the removal of various subsidies and measures to cut the public sector wage bill. The Egyptian government lowered wages as much as possible to discourage graduates from applying to its guaranteed employment scheme. By 1987, the salaries of government employees had fallen to 55 percent of their level in 1973, forcing employees to take second and even third jobs (Wickham 2002, p. 47). ${ }^{36}$ Many educated and once comfortable members of the middle class slid into the ranks of the urban poor. State subsidies on basic goods such as rice, sugar, cooking oil, fuel and transportation were also significantly reduced or removed altogether, leading to urban riots in Egypt in 1977 and in Morocco, Tunisia, Lebanon, Algeria and Jordan in the 1980s (Bayat 2002, p. 2). Even within the public sector, the income gap between the top bureaucratic levels and the lower levels of state officials and civil servants widened, resulting in repeated strikes and sit-ins by public sector workers in the 1980s (Ayubi 1989, p. 11).

\subsubsection{Personal Multiplier Effects}

Reference-dependent preferences can make an $L$ class member's objective function nonconcave. This leads to jumps in religiosity that are not captured by the local comparative statics results set out in Proposition 3. To illustrate this point we plot the payoff to an $L$ class member as a function of religious participation $r$ for different values of upward mobility $\mu_{i}$. Figure $2(\mathrm{a})$ depicts the case in which $\mu_{i}=0.7$. Notice that the objective function is maximized at a relatively low level of religiosity, but is double-peaked. As $\mu_{i}$ increases, the right-hand peak rises above the left-hand one, as shown in Figure 2(b), inducing a discontinuous jump to a higher level of religiosity. Hence it may only require small changes in upward social mobility to induce those stuck in the $L$ class to break away and immerse themselves in religion. ${ }^{37}$

\subsection{Education \& Aspirations}

Let us complete the model by characterizing the equilibria of the entire game. Thus far, we have characterized the equilibria of each subgame emanating from a given profile of

\footnotetext{
${ }^{36}$ For example, it became increasingly common for educated civil servants to work as taxi drivers during the evenings.

${ }^{37}$ Iannacconne (1988) develops a theory of sect formation based on a different form of non-concavity of individual objective functions.
} 


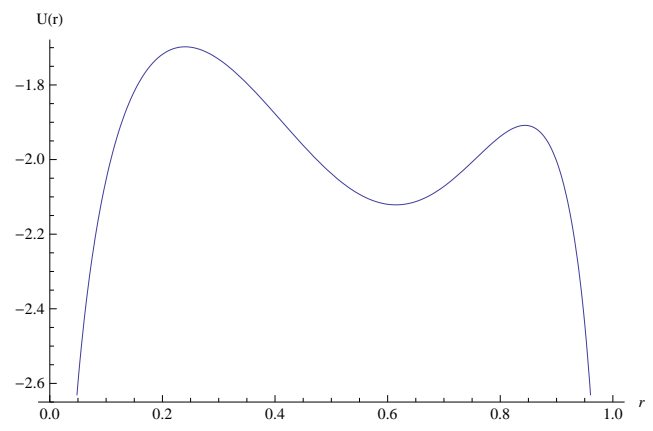

(a) Low religiosity

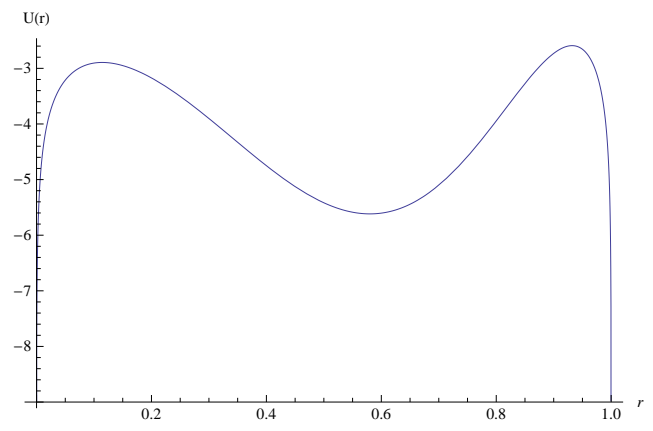

(b) High religiosity

Figure 2: Utility for an $L$ class member when $\mu_{i}$ equals (a) 0.7 and (b) 0.9. Throughout, $w_{L}=\delta=2, \gamma=5, y_{H}=3$ and $F(r)=\ln (r)$.

education choices $\mathbf{e} \equiv\left(e_{i}\right)_{i \in I}$. Although there may be multiple PE of each subgame, our comparative statics results will be the same in every equilibrium. We shall now study equilibrium education choice at date 1 .

To define a personal equilibrium of the entire game, recall that equilibrium religious participation in the religion subgame, conditional on education choice $e$, is characterized by the pair $r_{i}(e)=\left(r_{i L}(e), r_{H}\right)$ for each $i \in I$. We can now write the date-1 expected payoff for the entire game as $U_{i}\left(e, r_{i}(e) ; Y_{i}(e)\right)$ for agent $i$ with education $e$.

Definition 2. A personal equilibrium $[\mathrm{PE}]$ of the entire game consists of:

(i) For every e, a $\mathrm{PE}$ of the religion subgame characterized by a pair of religious participation choices $r_{i}\left(e_{i}\right)=\left(r_{i L}\left(e_{i}\right), r_{H}\right)$ for each $i \in I$,

(ii) Optimal education choices $\mathbf{e}^{*} \equiv\left(e_{i}^{*}\right)_{i \in I}$ at date 1 , such that $U_{i}\left(e^{*}, r_{i}\left(e^{*}\right) ; Y_{i}\left(e^{*}\right)\right) \geq$ $U_{i}\left(e, r_{i}(e) ; Y_{i}(e)\right)$ for all $e \in[0,1]$ and $i \in I$.

Following education choice $e$, the equilibrium continuation payoffs for agent $i$ if he ends up in the $H$ class and $L$ class are respectively:

$$
\begin{aligned}
V_{H} & =w_{H}\left(1-r_{H}\right)+F\left(r_{H}\right), \\
V_{i L}(e) & =w_{L}\left(1-r_{i L}(e)\right)+F\left(r_{i L}(e)\right)-\left(1-r_{i L}(e)\right)^{\delta} \mu_{i}(e)^{1+\gamma}\left[y_{H}-w_{L}\left(1-r_{i L}(e)\right)\right]^{1+\gamma}(5)
\end{aligned}
$$


where $\mu_{i}(e) \equiv \theta e+(1-\theta) B_{i}$ is agent $i$ 's probability of upward mobility. We can then write agent $i$ 's date- 1 expected utility, from choosing $e$, as:

$$
U_{i}\left(e, r_{i}(e) ; Y_{i}(e)\right)=\mu_{i}(e) V_{H}+\left(1-\mu_{i}(e)\right) V_{i L}(e)-k\left(e, a_{i}\right)
$$

where $k\left(e_{i}, a_{i}\right)$ is the cost of education.

Inspect the third term in the expression for $V_{i L}(e)$ in (5). Although a higher degree of education increases the likelihood that an individual enters the $H$ class, this term indicates that it also raises expectations and thereby unfulfilled aspirations should the agent fail to do so. To insure against unfulfilled aspirations then, agents might depress their level of education. We call this the keeping-down-expectations [KDE] effect on education choice; we are unaware of any prior theoretical work on this effect.

Utilizing the envelope theorem when differentiating $V_{i L}(e)$, the first-order condition for education choice is:

$$
\theta\left(V_{H}-V_{i L}(e)\right)+\underbrace{\left.\left(1-\mu_{i}(e)\right) \frac{\partial V_{i L}\left(e_{i}\right)}{\partial e_{i}}\right|_{e_{i}=e}}_{K D E \text { effect }}=k_{1}\left(e, a_{i}\right)
$$

The first term in (7) is a standard incentive effect. The second term is the KDE effect which is negative and can thus depress education choice relative to the benchmark in which agents do not have reference-dependent preferences. Analyzing this expression leads to the following result:

Proposition 4 There exists at least one personal equilibrium [PE] of the entire game. In every PE, $0<\mu_{i}\left(e_{i}^{*}\right)<1$ for all $i \in I$.

The proof of this and all remaining propositions is contained in the appendix.

Let us now turn to the comparative statics of education choice. Due to the KDE effect, the impact on education of social mobility and inequality is nontrivial and depends crucially on the equilibrium likelihood that an agent ends up in the $H$ class, $\mu_{i}\left(e_{i}^{*}\right)$. 
Proposition 5 In every PE, the education choice $e_{i}^{*}$ for each agent $i \in I$ is locally strictly increasing:

(i) in $a_{i}$, and if the likelihood of upward mobility $\mu_{i}\left(e_{i}^{*}\right)$ is sufficiently high:

(ii) in the high class wage $w_{H}$, and

(iii) social mobility $\theta$.

Let us propose two interpretations of the shift parameter $a_{i}$. Suppose that $a_{i}$ represents agent $i$ 's ability. In this case, part (i) of the proposition implies that the more talented individuals in society acquire higher levels of education and are more disappointed when they end up in the $L$ class. Under certain conditions, characterized in Proposition 3, these individuals will choose higher levels of religious participation. Suppose instead that $a_{i}=a$ represents the size of a common educational subsidy. (Recall from section 3 that the Egyptian government substantially increased funding for education after 1952.) According to part (i), subsidizing education increases educational attainment. By Proposition 3, however, this raises unfulfilled aspirations and, under certain conditions, religious participation among those who fail to achieve upward mobility.

The intuition behind parts (ii)-(iii) of the proposition is as follows. In responding to a rise in social mobility $\theta$, agents face countervailing pressures on education choice. On the one hand, they want to raise education to increase their expected income. On the other hand, they want to lower their education to keep down expectations and thereby insure against the disappointment of ending up in the $L$ class. If an agent faces a high likelihood of upward mobility ( $\mu_{i}^{*}$ is high), then he is less concerned with the prospect of ending up in the $L$ class. He will thus take on more education in response to a rise in social mobility. In contrast, educational attainment may be decreasing in the social mobility parameter $\theta$ for those with poor prospects. The same reasoning applies to inequality, which is determined by the $H$ class wage $w_{H}$. Higher inequality may induce those with poor prospects to invest less in education. These novel results are due to the KDE effect. Further exploration of this effect is beyond the scope of the present analysis, but is worthy of treatment in future research. 


\subsection{Social Mobility \& Overall Religiosity}

Thus far, we have focused on religiosity among individuals who end up in the $L$ class. We shall now examine the determinants of average religiosity across all agents $i \in I$. When social mobility $\theta$ is known to be low (an entrenched class-based society), individuals who start out in the $L$ class and remain stuck there are not very disappointed. But there are a lot of them. When $\theta$ is known to be high (a meritocratic society), unfulfilled aspirations are high among individuals who start out in the $L$ class and remain stuck there, but there are relatively few of them. This nexus is, however, broken by unexpected shocks to social mobility. We shall proceed to show that, under certain conditions, an unexpected decline in social mobility can lead to a high level of unfulfilled aspirations among a relatively large number of agents.

Assume now that social mobility is stochastic. Let the social mobility parameter be a random variable $\Theta$ and let $\theta$ be its realization. Define $\bar{\theta} \equiv E[\Theta]$ as expected social mobility, where the expectation is formed at date 1 , and $\Delta \theta \equiv \theta-\bar{\theta}$ as the gap between actual and expected mobility. We assume that $\theta$ is learned by agents only after all decisions are made at date

3 , so that education and labor supply choices depend only upon $\bar{\theta}$. Because social mobility enters the utility function via $\mu_{i}=\bar{\theta} e_{i}+(1-\bar{\theta}) B_{i}$ as a point estimate, all our previous results follow through, with $\theta$ replaced by $\bar{\theta}$. To fit with our application to Egypt, we refer to $\Delta \theta<0$ as a 'decline' in social mobility (even though no prior stage has yet been modeled).

Let $R$ be ex post average religious activity across all agents defined as:

$R=\int_{I}\left[(\bar{\theta}+\Delta \theta) e^{*}(i)+(1-\bar{\theta}-\Delta \theta) \beta(i)\right] r_{H} d \lambda+\int_{I}\left\{1-\left[(\bar{\theta}+\Delta \theta) e^{*}(i)+(1-\bar{\theta}-\Delta \theta) \beta(i)\right]\right\} r_{L}(i) d \lambda$,

where $r_{H}, r_{L}(i)$ and $e^{*}(i)$ are the equilibrium values characterized in Propositions 1 and 4 . Since for every $i \in I, r_{H}, r_{i L}$ and $e_{i}^{*}$ depend on $\bar{\theta}$ only and not $\Delta \theta$, we have:

$$
\frac{d R}{d \Delta \theta}=\int_{I}\left[e^{*}(i)-\beta(i)\right]\left(r_{H}-r_{i L}\right) d \lambda
$$

Let $\mathcal{I} \equiv\left\{i: \beta_{i}=1\right\}$. As $\lambda(\mathcal{I}) \rightarrow 0$, viz. the set of agents who start out in the $H$ class is sufficiently small, then (9) goes to: 


$$
\frac{d R}{d \Delta \theta}=\int_{I} e^{*}(i)\left(r_{H}-r_{i L}\right) d \lambda .
$$

For a decline in social mobility to cause an increase in overall religious activity, $d R / d \Delta \theta<0$, it is thus sufficient that $r_{i L}>r_{H}$ for all $i \in I$. As we show in the appendix, this occurs if for all $i \in I$ :

$$
y_{H}-y_{i L}>\frac{1+\gamma}{\delta} \frac{y_{i L}}{\mu_{i}} .
$$

This is the same as the now familiar condition which determines the sign of the relationship between inequality/mobility expectations and religiosity, except that $1+\gamma$ features on the right-hand side, not $\gamma$. In other words, a decline in social mobility leads to greater overall religiosity $R$ if income inequality is above some threshold, which depends on expected social mobility $\bar{\theta}$. When expected social mobility is low $\bar{\theta}$, agents who end up in the $L$ class attempt to live up to their expectations by working harder and spending less time on religious participation. This means that a decline in social mobility can reduce average religiosity under certain conditions. Hence it is the combination of high expectations and an unexpected decline in social mobility which generates a rise in average religiosity. Rather than undermining religious participation, our analysis suggests that economic development, by raising aspirations, can make societies more prone to religious revivals.

Proposition 6 In every PE of the game, for $\lambda(\mathcal{I})$ sufficiently small, an unexpected decline in social mobility $(\Delta \theta<0)$ leads to an increase in average religiosity $R$ if $y_{H}-y_{i L}>\frac{1+\gamma}{\delta} \frac{y_{i L}}{\mu_{i}}$ for all $i \in I$.

Thus, by introducing reference-dependent preferences and religious values to a neoclassical model of labor supply, we suggest that raised aspirations, a decline in social mobility, rising inequality and poverty are all intimately related causes of a religious revival and that none of these factors can be viewed in isolation.

\subsection{Club Goods and Social Multiplier Effects}

Let us now examine how the psychological function of religion analyzed thus far interacts with standard conceptions of religion in the economics of religion literature. Firstly, following 
Iannaccone (1992), club goods models of religion focus on strategic complementarities in religious production. Secondly, following Iannaccone (1990), religious capital models suppose that religious participation by an individual today generates (personal) religious capital which increases the individual's future religious participation. ${ }^{38}$ We shall now embed our model of religion in a dynamic framework that features elements of both of these approaches. We demonstrate how social multiplier effects can arise in this setting. In particular, supplyside factors could amplify the effects of a shock to religious demand.

In particular, we augment the function $F$, which represents the leisure utility from religious participation to $F(r, K)$ which is a function of religious participation $r$ and a variable that we shall call religious capacity $K$. As before, we assume that $F_{1}(r, K)>0, F_{11}(r, K)<0$ and $F_{1}(r, K) \rightarrow \infty$ as $r \rightarrow 0$ for all $K$. Now let $F_{12}(r, K)>0$, so that religious capacity increases equilibrium religious participation for all agents. In addition, assume that $F_{1}(r, K)>0$ for all $K$ and $F_{12}(r, K) \rightarrow 0$ as $K \rightarrow \infty$.

Religious capacity will be determined endogenously by the following dynamic process. Time is discrete and denoted by $t=0,1,2, \ldots$. We can conceive of a birth-death chain in which each period, with positive probability, an agent dies leaving one offspring which starts out with its parent's class status. Let $K_{t}$ be religious capacity at time $t$ and $K_{0}$ be an arbitrary initial capacity. The law of motion for capacity is:

$$
K_{t+1}=(1-d) K_{t}+G\left(R_{t}\right)
$$

where $d \in(0,1)$ is a depreciation rate, $G$ is a strictly increasing function with $G()>$.0 and $R_{t}$ is aggregate religious activity in period $t$. Current religious participation thus affects future participation via increased religious capacity. Hence we can interpret religious capacity as both the capacity of religious organizations (for example, to deliver social services) and a form of religious capital that is socially produced. In this way, our dynamic extension integrates features of a club goods and religious capital model, and explores how they interact with reference-dependent preferences.

Since agents are nonatomic, they cannot individually affect $R_{t}$ and hence the evolution of $K$. Therefore, even though they may be long lived, agents face the same problem as (3) in choosing religious participation, so that $R_{t}$ is once again given by (8). Thus, there exists

\footnotetext{
${ }^{38}$ See McBride (2007) for a different club goods model with religious capital formation.
} 


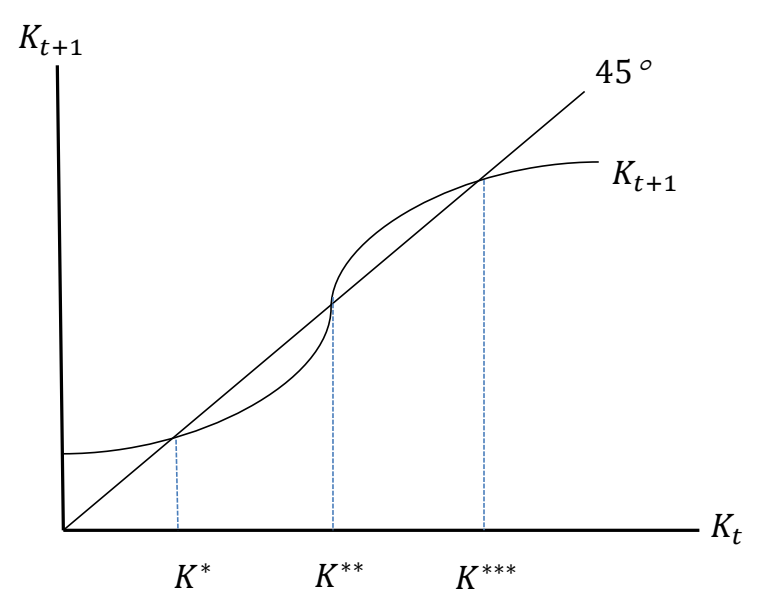

(a) Low religiosity

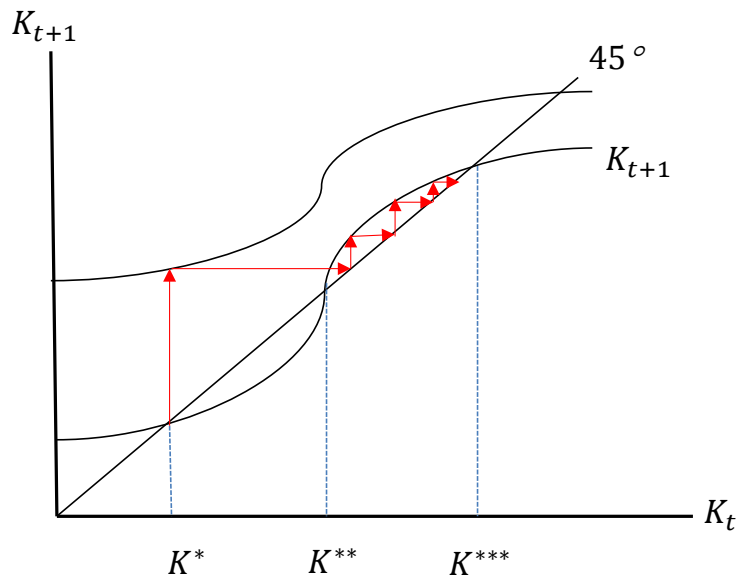

(b) High religiosity

Figure 3: (a) Multiple steady-state levels of religious capacity. (b) A temporary shock to social mobility induces a large, permanent increase in religious participation/capacity.

a severe-free-rider problem in building religious capacity to deliver social services and other benefits.

The dynamics of religious capacity are depicted in Figure 2. A steady state occurs where $G\left(R_{t}\right)=d K_{t}$. $R_{t}$ is strictly increasing in $K_{t}$ because $F_{12}\left(r, K_{t}\right)>0$. In addition, $R_{t}$ is greater than zero when $K_{t}=0$ because $F_{1}(r, 0)>0$ and $R_{t}$ approaches some limit $\bar{R}>0$ as $K_{t} \rightarrow \infty$ because $F_{12}(r, K) \rightarrow 0$ as $K \rightarrow \infty$. Depending on the function $G$, there could be multiple steady states. From any initial state $K_{0}$, the process converges to a steady state with probability one. The social multiplier effects that can be produced by multiple steady states will be the focus of our remaining analysis. There are precisely three steady states in the example in Figure 2(a): $K^{*}$ and $K^{* * *}$ are asymptotically stable, while $K^{* *}$ is not.

We have shown that if the elite is sufficiently small and inequality is sufficiently high, an unexpected decline in social mobility increases total religious participation (Proposition 6). This amounts to an upward shift of the $R_{t}$ function. Figure 2(b) depicts a case in which this eliminates the low capacity steady states. As expectations of social mobility adjust in the next period, the $R_{t}$ function shifts back, reintroducing the low capacity steady states. Nevertheless, the arrows in Figure 2(b) indicate that even this one-period decline in social mobility could shock the economy out of the lowest capacity steady state $K^{*}$ into the highest 
one $K^{* * *}$. In other words, a temporary shock to social mobility could lead to a large and permanent increase in religious participation and capacity. In this way, the psychological function of religion can help to attenuate the free-rider problem in the provision of religious capacity.

The religious revival depicted in Figure 2(b) has a particular life cycle. During the period of the shock, the rise in religious participation is driven mainly by educated and talented individuals [see Propositions 3(iii) and 5(i)]. As religious capacity builds and expectations adjust, the psychological role for religion declines and other motivations take over. The religious revival thus becomes a widespread phenomenon affecting religious participation among the $H$ class as well as the less educated segments of the $L$ class.

\section{Conclusion}

Egypt's political revolution of January 2011 was preceded by a cultural transformation. This paper links the Islamic revival in Egypt since the 1970-80s to an unexpected decline in social mobility. We make two contributions to the literature. Firstly, we exploit nationallyrepresentative household survey data to present the first microeconomic evidence of a decline in social mobility among educated Egyptian youth, which we link to a decline in public sector employment. Secondly, we develop a formal model in which agents have reference-dependent preferences and unfulfilled aspirations are a form of loss aversion. When religion performs a psychological function in helping to cope with loss, we derive a simple necessary and sufficient condition for an increase in unfulfilled aspirations to produce a rise in religious participation. We proceed to show how a (once-off) decline in social mobility could give rise to a widespread and long-lasting Islamic revival, led by the educated middle class.

Why Islam? It is conceivable that socialism would have been the popular response, had (pan-Arab) socialism and capitalism not been widely viewed as causes of economic stagnation and inequality. The most plausible reason for the turn to Islam, however, is its egalitarian emphasis and effectiveness in compensating for loss, defined here in pecuniary terms. Michalopoulos et al. (2012) present evidence that Islam is a relatively egalitarian moral system that emerged and spread to deal with deep economic inequalities. In addition, Islamic organizations were less easily repressed than secular opposition groups, because government agencies could not interfere too egregiously in the sacred sphere of the mosque and 
because close-knit, informal networks of independent mosques, Islamic business and social organizations were already well established (e.g. Kuran 1998).

To the extent that Egyptian trends were mirrored elsewhere, our analysis may have implications for the broader Islamic revival in the Muslim world. Between 1980 and 1993, the Middle East and North African region exhibited the worst growth performance of any region in the world with average annual GNP per capita growth of -2.3 percent (Richards \& Waterbury 1996, p. 64-5). In 1995, real wages and labor productivity were around the same level as in 1970 (Richards \& Waterbury 1996, p. 64). Pissarides \& Veganzones-Varoudakis (2005, p. 5-6) document a large decline in total factor productivity in MENA nations beginning in the 1970s, and in this respect the region compares poorly even with sub-Saharan Africa. Despite the shared experience of economic stagnation, the Islamic revival is a complex phenomenon and we do not suggest that raised aspirations combined with a decline in social mobility among the educated is the only driving force behind it, even in Egypt. Time-series data on religiosity in Muslim societies dating from the 1960s would be required to test the theory, but is as yet unavailable.

For now, we can tentatively point to other examples of religious revivals amidst deteriorating economic conditions. Fogel (2000) describes the history of four great Christian awakenings in the United States. The most recent one, during the 1980s and 1990s, did not occur among mainline Protestant churches, but stricter Evangelical denominations and sects such as the Mormons and Seventh-day Adventists (e.g. Berger 1999). This occurred amidst a background of declining social mobility and rising income inequality. In addition, Latin America - once uniformly Catholic - experienced "an explosion of conservative evangelical religion, a shift toward Pentecostalism, a rejection of ecumenism" (Martin 1990, p. 54). This coincided with a reversal in economic growth in the region (Loayza et al. 2005).

\section{References}

Akerlof, G. A. \& Kranton, R. E. (2000), 'Economics and identity', Quarterly Journal of Economics 415(3), 715-753.

Akerlof, G. A. \& Kranton, R. E. (2010), Identity Economics: How our Identities Shape our Work, Wages and Wellbeing, Princeton University Press, Princeton, NJ. 
Amin, G. A. (1995), Egypt's Economic Predicament, E.J Brill, Leiden, Netherlands.

Assaad, R. (1997), 'The effects of public sector hiring and compensation policies on the Egyptian labor market', World Bank Economic Review 11(1), 85-118.

Assaad, R. (2007), Institutions, household decisions, and economic growth in Egypt, in J. B. Nugent \& M. H. Pesaran, eds, 'Explaining Gowth in the Middle East', Elsevier, Amsterdam, chapter 13, pp. 385-411.

Assaad, R. (2009), Labor supply, employment, and unemployment in the Egyptian economy, 1988-2006, in R. Assaad, ed., 'The Egyptian Labor Market Revisited', The American University Cairo Press, Cairo, New York, chapter 1, pp. 1-52.

Assaad, R. \& El Hamidi, F. (2009), Women in the Egyptian labor market: an analysis of developments, 1988-2006, in R. Assaad, ed., 'The Egyptian Labor Market Revisited', The American University Cairo Press, Cairo, New York, chapter 7, pp. 259-284.

Atkinson, A. B. (2003), 'Income inequality in OECD countries: data and explanations', CESifo Working Paper No. 881.

Austen-Smith, D. \& Fryer, R. G. (2005), 'An economic analysis of "acting white"', Quarterly Journal of Economics 120(2), 551-583.

Ayubi, N. (1989), Government and the state in Egypt today, in C. Tripp \& R. Owen, eds, 'Egypt Under Mubarak', Routledge, New York, NY, pp. 1-20.

Ayubi, N. (1991), Political Islam: Religion and Politics in the Arab World, Routledge, London, UK.

Azem, A. J. (1997), The Islamic Action Front Party, Al-Urdun Al-Jadid Research Center, Amman, Jordan, pp. 95-144.

Bainbridge, W. S., ed. (1997), The Sociology of Religious Movements, Routledge, New York, NY.

Barro, R. \& Lee, J.-W. (2010), A New Data Set of Educational Attainment in the World, 1950-2010, NBER Working Paper 15902.

Bayat, A. (2002), 'Activism and social development in the Middle East', International Journal of Middle East Studies 34, 1-28.

Bayat, A. (2007), Making Islam Democratic, Stanford University Press, Stanford, CA.

Becker, G. S. \& Tomes, N. (1986), 'Human capital and the rise and fall of families', Journal of Labor Economics 4(3).

Bénabou, R. J. \& Tirole, J. (2002), 'Self-confidence and personal motivation', Quarterly Journal of Economics 117(3), 871-915. 
Bénabou, R. \& Tirole, J. (2006), 'Belief in a just world and redistributive politics', Quarterly Journal of Economics 121(2), 699-746.

Berger, P. L. (1999), The desecularization of the world: A global overview, in P. L. Berger, ed., 'The desecularization of the world: resurgent religion and world politics', Ethics and Public Policy Center, Washington D.C., pp. 1-18.

Berman, E. (2000), 'Sect, subsidy, and sacrifice: an economist's view of ultra-orthodox Jews', Quarterly Journal of Economics 115(3), 905-953.

Binder, M. \& Woodruff, C. (2002), 'Inequality and intergenerational mobility in schooling: the case of Mexico', Economic Development and Cultural Change 50(2), 249-267.

Bisin, A. \& Verdier, T. (2000), 'Beyond the melting pot: cultural transmission, marriage, and the evolution of ethnic and religious traits', Quarterly Journal of Economics 115(3), 955988.

Blaydes, L. \& Chaney, E. (forthcoming), 'The feudal revolution and europe's rise: political divergence of the Christian west and the Muslim world before 1500 CE', American Political Science Review .

Bowles, S. \& Park, Y. (2005), 'Emulation, inequality, and work hours: was Veblen right?', Economic Journal 115, 397-412.

Carvalho, J.-P. (2013), 'Veiling', Quarterly Journal of Economics 128(1), 337-370.

Carvalho, J.-P. \& Koyama, M. (2012), Development and religious polarization: the emergence of reform and ultra-orthodox Judaism. mimeo.

Chaney, E. (2011), Separation of powers and the medieval roots of institutional divergence between Europe and the Islamic Middle East. mimeo.

Chaney, E. (2012), Revolt on the Nile: economic shocks, religion and political power. mimeo.

Chen, D. L. (2010), 'Club goods and group identity: evidence from Islamic resurgence during the Indonesian financial crisis', Journal of Political Economy 118(2), 300-354.

Clark, A. E. \& Oswald, A. J. (1998), 'Comparison-concave utility and following behaviour in social and economic settings', Journal of Public Economics 70(1), 133-155.

Clark, J. (2004), 'Social movement theory and patron-clientelism: Islamic social institutions and the middle class in Egypt, Jordan, and Yemen', Comparative Political Studies 37(8), 941-968.

Clingingsmith, D., Khwaja, A. I. \& Kremer, M. (2009), 'Estimating the impact of the Hajj: religion and tolerance in Islam's global gathering', Quarterly Journal of Economics 124(3), 1133-1170. 
Crawford, V. P. \& Meng, J. (2011), 'New York City cabdrivers' labour supply revisited: reference-dependent preferences with rational-expectations targets for hours and income', American Economic Review 101(5), 1912-32.

de Tocqueville, A. (1856/1986), L'Ancien R'egime et la R'evolution, Robert Laffont, Paris.

Dehejia, R., DeLeire, T. \& Luttmer, E. (2007), 'Insuring consumption and happiness through religious organizations', Journal of Public Economics 91(1-2), 259-279.

Dunn, C. (2007), 'The intergenerational transmission of lifetime earnings: evidence from Brazil', The B.E. Journal of Economic Analysis 83 Policy 7(2).

Economic Research Forum (ERF) (2006), 'Egypt Labor Market Panel Survey of 2006. Publicly Accessible Database, Cairo, Egypt (www.erf.org.eg)'.

Ellison, C. (1993), Religion, the life stress paradigm, and the study of depression, in J. S. Levin, ed., 'Religion in Aging and Mental Health: Theoretical Foundations and Methodological Frontiers', Sage, Thousand Oaks, CA, pp. 78-121.

Erikson, R., Goldthorpe, J. H. \& Portocarero, L. (1983), 'Intergenerational class mobility and the convergence thesis: England, France and Sweden', British Journal of Sociology 34(3), 303-343.

Esposito, J. L. (1999), The Islamic Threat: Myth or Reality?, Oxford University Press, Oxford.

Esposito, J. L., Haddad, Y. Y., Moore, K., Sawan, D. \& Voll, J. O. (1991), The Contemporary Islamic Revival: A Critical Survey and Bibliography, Greenwood Press, Westport, CT.

Fang, H. \& Loury, G. C. (2005), "Dysfunctional identities" can be rational', American Economic Review, Papers \&3 Proceedings 95(2), 104-111.

Fogel, R. W. (2000), The Fourth Great Awakening and the Future of Egalitarianism, University of Chicago Press, Chicago, IL.

Grawe, N. D. (2004), Intergenerational mobility for whom?, in M. Corak, ed., 'Generational Income Mobility in North America and Europe', Cambridge University Press, Cambridge.

Hanushek, E. A. \& Woessmann, L. (2007), The role of education quality for economic growth, World Bank Policy Research Working Paper 4122.

Hertz, T., Jayasundera, T., Piraino, P., Selcuk, S., Smith, N. \& Verashchagina, A. (2007), 'The inheritance of educational inequality: international comparisons and fiftyyear trends', The B.E. Journal of Economic Analysis 83 Policy 7(2).

Hertz, T., Meurs, M. \& Selcuk, S. (2009), 'The decline in intergenerational mobility in post-socialism: evidence from the Bulgarian case', World Development 37(3), 739-752. 
Hirschkind, C. (2006), The Ethical Soundscape: Cassette Sermons and Islamic Counterpublics, Columbia University Press, New York, NY.

Hoffman, V. (1995), Muslim fundamentalists: psychosocial profiles, in M. E. Marty \& R. S. Appleby, eds, 'Fundamentalisms Comprehended, Vol. 5 of the Fundamentalism Project', University of Chicago Press, Chicago, IL, pp. 199-230.

Hoodfar, H. (1997), Between Marriage and the Market - Intimate Politics and Survival in Cairo, University of California Press, Berkeley, CA.

Hourani, A. (2005), A History of the Arab Peoples, Faber and Faber, London, UK.

Hunter, S. T., ed. (1988), The Politics of Islamic Revivalism: Diversity and Unity, Center for Strategic and International Studies, Washington D.C.

Iannaccone, L. R. (1990), 'Religious practice: a human capital approach', Journal for the Scientific Study of Religion pp. 297-314.

Iannaccone, L. R. (1992), 'Sacrifice and stigma: reducing free-riding in cults, communes, and other collectives', Journal of Political Economy 100(2), 271-291.

Iannaccone, L. R. (1998), 'Introduction to the economics of religion', Journal of Economic Literature 36(3), 1465-1495.

Iannaccone, L. R., Haight, C. E. \& Rubin, J. (2011), 'Lessons from Delphi: religious markets and spiritual capitals', Journal of Economic Behavior 63 Organization 77(3), 326 - 338.

Iannacconne, L. (1988), 'A formal model of church and sect', American Journal of Sociology 94, 241-268.

Ibrahim, S. E. (1980), 'Anatomy of Egypt's militant Islamic groups: methodological note and preliminary findings', International Journal of Middle East Studies 12(4), 423-453.

James, W. (1890/1974), Varieties of Religious Experience: A Study in Human Nature, Collins, London, UK.

Jensen, R. (2010), 'The (Perceived) Returns to Education and the Demand for Schooling', Quarterly Journal of Economics 2(125), 515-548.

Kahneman, D. \& Tversky, A. (1979), 'Prospect theory: an analysis of decision under risk', Econometrica 47(2), 263-291.

Köszegi, B. \& Rabin, M. (2006), 'A model of reference-dependent preferences', Quarterly Journal of Economics 121(4), 1133-1165.

Kuran, T. (1998), 'The vulnerability of the Arab state: reflections on the Ayubi thesis', The Independent Review 8(1), 111-123. 
Kuran, T. (2004a), 'The economic ascent of the Middle East's religious minorities: the role of Islamic legal pluralism', Journal of Legal Studies 33, 475-515.

Kuran, T. (2004b), Islam and Mammon: The Economic Predicaments of Islamism, Princeton University Press, Princeton, NJ.

Kuran, T. (2004c), 'Why the Middle East is economically underdeveloped: historical mechanisms of institutional stagnation', Journal of Economic Perspectives 18, 71-90.

Kuran, T. (2010), The Long Divergence: How Islamic Law Held Back the Middle East, Princeton University Press, Princeton, NJ.

Lapidus, I. M. (2002), A History of Islamic Societies, Cambridge University Press, Cambridge.

Loayza, N., Fajnzylber, P. \& Calderón, C. (2005), Economic Growth in Latin America and the Caribbean: Stylized Facts, Explanations, and Forecasts, World Bank Publications, Washington D.C.

Loury, G. C. (1981), 'Intergenerational transfers and the distribution of earnings', Econometrica 49(4), 843-867.

Louw, M., van der Berg, S. \& Yu, D. (2007), 'Convergence of a kind: educational attainment and intergenerational social mobility in South africa', South African Journal of Economics $75(3), 548-571$.

Martin, D. (1990), Tongues of Fire: The Explosion of Pentecostalism in Latin America, Blackwell, Oxford UK.

Mazumdar, D. (1989), Microeconomic issues of labor markets in developing countries: analysis and policy implications, World Bank EDI Seminar Paper 40.

McBride, M. (2007), 'Why churches need free-riders: religious capital formation and religious group survival', working paper, University of California-Irvine.

Michalopoulos, S., Naghavi, A. \& Prarolo, G. (2012), 'Trade and geography in the origins and spread of Islam', working paper, Brown University.

Mitchell, R. P. (1993), The Society of Muslim Brothers, Oxford University Press, New York, NY.

Mookherjee, D. \& Ray, D. (2002), 'Contractual structure and wealth accumulation', American Economic Review 92(4), 818-849.

Morduch, J. (1995), 'Income smoothing and consumption smoothing', Journal of Economic Perspectives 9(3), 103-114.

Mutlu, K. (1996), 'Examining religious beliefs among university students in Ankara', British Journal of Sociology 47(2), 353-359. 
Ng, I. (2007), 'Intergenerational income mobility in Singapore', The B.E. Journal of Economic Analysis 83 Policy 7(2).

Nicoletti, C. \& Ermisch, J. F. (2007), 'Intergenerational earnings mobility: changes across cohorts in Britain', The B.E. Journal of Economic Analysis $\&$ Policy 7(2).

Norris, P. \& Inglehart, R. (2004), Sacred and Secular: Religion and Politics Worldwide, Cambridge University Press, Cambridge, UK.

Patel, D. S. (2012), 'Concealing to reveal: The informational role of Islamic dress in Muslim societies', Rationality and Society 24(3), 295-323.

Piketty, T. (1995), 'Social mobility and redistributive politics', Quarterly Journal of Economics 110(3), 551-584.

Pissarides, C. A. \& Veganzones-Varoudakis, M. A. (2005), 'Labour markets and economic growth in the MENA region', CERDI Working Paper No. 2005-35.

Platteau, J.-P. (2008), 'Religion, politics, and development: lessons from the lands of Islam', Journal of Economic Behavior \& Organization 68(2), 329-351.

Pritchett, L. (2001), 'Where has all the education gone?', The World Bank Economic Review 15(3), 367-391.

Richards, A. (1992), Higher education in Egypt, World Bank Policy Research Working Paper 862.

Richards, A. \& Waterbury, J. (1996), A Political Economy of the Middle East, Westview Press, Boulder, CO.

Richards, A. \& Waterbury, J. (2008), A Political Economy of the Middle East, 3rd edn, Westview Press, Boulder, Colo.

Rosenzweig, M. R. \& Wolpin, K. (1993), 'Credit market constraints, consumption smoothing, and the accumulation of durable production assets in low-income countries: investments in bullocks in India', Journal of Political Economy 101(2), 223-244.

Runciman, W. G. (1966), Relative Deprivation and Social Justice, Routledge \& Kegan Paul, London, UK.

Salehi-Isfahani, D. (2007), Microeconomics of growth in MENA: the role of households, in J. B. Nugent \& M. H. Pesaran, eds, 'Explaining Gowth in the Middle East', Elsevier, Amsterdam, chapter 6, pp. 159-194.

Shadid, M. K. (1988), 'The Muslim Brotherhood movement in the West Bank and Gaza', Third World Quarterly 10(2), 658-682.

Shalev, J. (2000), 'Loss aversion equilibrium', International Journal of Game Theory 29(2), 269-287. 
Smith, T. B., McCullough, M. E. \& Poll, J. (2003), 'Religiousness and depression: evidence for a main effect and the moderating influence of stressful life events', Psychological Bulletin 129(4), 614-636.

Stark, R. (1999), 'Secularization, R.I.P.', Sociology of Religion 60(3), 249-273.

Udry, C. (1995), 'Risk and saving in northern Nigeria', American Economic Review 85(5), 1287-1300.

Valero-Gil, J. N. \& Tijerina-Guajardo, J. A. (2002), 'Effects of education on the intergenerational transmission of labor income in Mexico', Eastern Economic Journal 28(3), 381-392.

van Nieuwkerk, K. (2007), 'From repentance to pious performance', ISIM Review 20, 54-55.

Wallis, R. \& Bruce, S. (2001), Secularization: the orthodox model, in S. Bruce, ed., 'Religion and Modernization', Oxford University Press, Oxford, UK, pp. 8-30.

Waltz, S. (1986), 'Islamist appeal in Tunisia', Middle East Journal 40(4), 651-670.

Wickham, C. R. (2002), Mobilizing Islam: Religion, Activism and Social Change in Egypt, Columbia University Press, New York, NY.

World Bank (2004a), Gender and Development in the Middle East and North Africa: Women in the Public Sphere, Technical report, Washington, DC.

World Bank (2004b), Unlocking the Employment Potential in the Middle East and North Africa: Toward a New Social Contract, Technical report, Washington, DC.

World Values Survey (WVS) (2009), '1981-2008 Official Aggregate v.20090901, 2009. World Values Survey Association (www.worldvaluessurvey.org). Aggregate File Producer: ASEP/JDS, Madrid'. 


\section{Appendix}

\section{Mathematical Proofs}

Proof of Proposition 1. By definition:

$$
\begin{aligned}
Y_{i}-y_{i H} & =\mu_{i} y_{i H}+\left(1-\mu_{i}\right) y_{i L}-y_{i H} \\
& =-\left(1-\mu_{i}\right)\left(y_{i H}-y_{i L}\right) .
\end{aligned}
$$

Because $y_{i H}>y_{i L}$ for all agents in equilibrium, $Y_{i}-y_{i H} \leq 0$, so that $\left(Y_{i}-y_{i H}\right)_{+}=0$. Substituting into (3), the first-order condition when $i \in I_{H}$ is:

$$
\frac{1}{\left(1-r_{H}\right)}=F^{\prime}\left(r_{H}\right)
$$

where we have written $r_{i H} \equiv r_{H}$ because all $i \in I_{H}$ face the same first-order condition. (It is straightforward to check that the second order-condition for a maximum is satisfied.)

We shall now show that $r_{H} \in(0,1)$ in every equilibrium. By assumption, the left-hand side [LHS] of (14) increases continuously and monotonically from some positive number to $\infty$ and the RHS decreases continuously and monotonically from $\infty$ to some positive number as $r_{H}$ goes through the unit interval. Hence there exists a unique solution $r_{H}$ to (14) and $0<r_{H}<1$.

Notice that $r_{H}$ is independent of the choices of $L$ class members. Hence, in determining $r_{i L}$, $y_{H}=w_{H}\left(1-r_{H}\right)$ can be treated as a parameter. Compute:

$$
\begin{aligned}
Y_{i L}-y_{i L} & =\mu_{i} y_{i H}+\left(1-\mu_{i}\right) y_{i L}-y_{i L} \\
& =\mu_{i}\left(y_{i H}-y_{i L}\right)
\end{aligned}
$$

which is greater than or equal to zero in every equilibrium.

Holding $Y_{i}$ constant and differentiating (3) with respect to $r_{i}$ yields the first-order condition when $i \in I_{L}$ :

$$
\frac{1}{\left(1-r_{i L}\right)}+\delta\left(1-r_{i L}\right)^{\delta-1}\left(Y_{i}-y_{i L}\right)^{1+\gamma}-(1+\gamma) w_{L}\left(1-r_{i L}\right)^{\delta}\left(Y_{i}-y_{i L}\right)^{\gamma}=F^{\prime}\left(r_{i L}\right)
$$




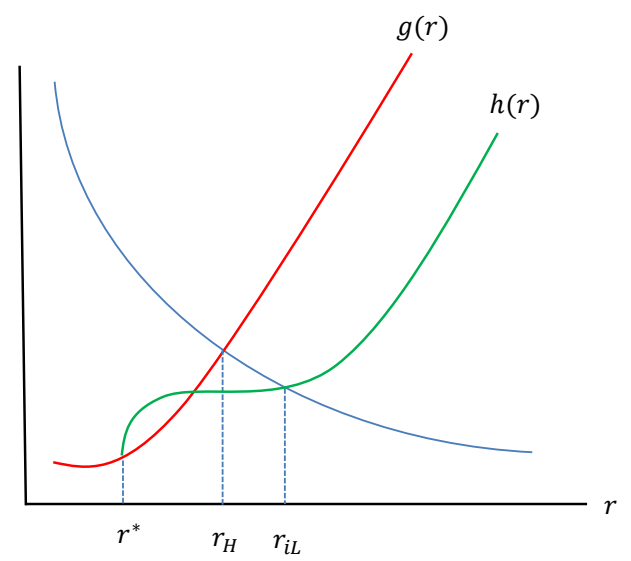

Figure 4

In equilibrium, $Y_{i}=\mu_{i} y_{H}+\left(1-\mu_{i}\right) y_{i L}$. Substituting this into (16), we have the equilibrium condition:

$$
\frac{1}{\left(1-r_{i L}\right)}+\delta\left(1-r_{i L}\right)^{\delta-1}\left[\mu_{i}\left(y_{H}-y_{i L}\right)\right]^{1+\gamma}-(1+\gamma) w_{L}\left(1-r_{i L}\right)^{\delta}\left[\mu_{i}\left(y_{H}-y_{i L}\right)\right]^{\gamma}=F^{\prime}\left(r_{i L}\right)
$$

By assumption, the RHS of (17) goes from $\infty$ to some positive number as $r_{H}$ goes through the unit interval. For $\delta \geq 0$, the LHS of (17) goes from some finite real number to $\infty$ as $r_{H}$ goes through the unit interval. Both functions are continuous. Hence there exists at least one solution $r_{i L}$ to $(17)$ ad $r_{i L} \in(0,1)$ for all $i$ in every equilibrium.

All that is left to show is that in the proposed equilibrium $y_{H}>y_{i L}$ for all $i \in I$. If $y_{H}>w_{L}$, then this is clearly true for all agents. Suppose not. Define $r^{*}$ as the solution to $y_{H}=w_{L}\left(1-r^{*}\right)$. Denote the LHS of (14) and (17) as $g(r)$ and $h(r)$ respectively. Observe that $g\left(r^{*}\right)=h\left(r^{*}\right)$. In addition, $r^{*}<r_{H}$ because $w_{H}>w_{L}$. By inspection of Figure 4 then, $r_{i L}>r^{*}$ for all $i \in I$. Hence $y_{i L}=w_{L}\left(1-r_{i L}\right)<w_{L}\left(1-r^{*}\right)=y_{H}$.

Proof of Proposition 4. By Proposition 3, for each $\mathbf{e} \equiv\left(e_{i}\right)_{i \in I}$ there exists at least one $\mathrm{PE}$ of the religion subgame. For each e, fix a PE of the ensuing religion subgame. We shall now show that there exists an optimal education choice for each agent at date 1 . Calculating $\partial V_{i L}\left(e_{i}\right) /\left.\partial e_{i}\right|_{e_{i}=e}$ from (5) and substituting into (7), we can rewrite the first-order condition as:

$$
\theta\left(V_{H}-V_{i L}(e)\right)-(1+\gamma) \theta\left(1-\mu_{i}(e)\right)\left(1-r_{i L}\right)^{\delta} u_{i}(e)^{\gamma}\left(y_{H}-w_{L} h_{i L}\right)^{1+\gamma}=k_{1}\left(e, a_{i}\right) .
$$


By the assumptions on $k$, the RHS of (18) increases monotonically from zero to infinity as $e$ goes through the unit interval. Suppose $B_{i}=0$. Then when $e=0$, the LHS of (18) equals $V_{H}-V_{i L}(0)>0$. Since $V_{H}$ and $V_{i L}(e)$ are bounded, the LHS equals some finite real number when $e=1$. Both sides of (18) are continuous functions of $e$. Hence, by the intermediate-value theorem, the curve represented by the LHS crosses $k_{1}\left(e, a_{i}\right)$ from above at least once and every crossing lies in $(0,1)$. It immediately follows that there exists at least one solution to (18), which satisfies the second-order condition for a maximum. The set of local maximizers contains the global maximizer which we denote by $e_{i}^{*}$. Now suppose that $B_{i}=1$. The only difference is that the LHS may be negative when $e=0$, introducing the possibility that $e_{i}^{*}=0$ for agents who begin in the $H$ class. This establishes the existence of a PE.

We know that if $B_{i}=0, e_{i} \in(0,1)$. Hence for all such agents $\mu_{i}=\theta e_{i} \in(0,1)$. If $B_{i}=1$, $e_{i} \in[0,1)$. Hence for all such agents $\mu_{i}=\theta e_{i}+(1-\theta) \in(0,1)$. This establishes the proposition.

Proof of Proposition 5. The only direct effect of $a_{i}$ on the first-order condition (7) is $k_{12}<0$. Therefore, $d e_{i}^{*} / d a_{i}>0$ which establishes part (i).

To establish (iii), partially differentiate the LHS of (7) with respect to $\theta$, utilizing the envelope theorem. This yields:

$$
\begin{aligned}
V_{H}-V_{i L}(e) & +(1+\gamma) \theta e\left(1-r_{i L}(e)\right)^{\delta} \mu_{i}(e)^{\gamma}\left[y_{H}-w_{L}\left(1-r_{i L}(e)\right)\right]^{1+\gamma} \\
+ & (1+\gamma) \theta e\left(1-r_{i L}(e)\right)^{\delta} \mu_{i}(e)^{\gamma}\left[y_{H}-w_{L}\left(1-r_{i L}(e)\right)\right]^{1+\gamma} \\
& \quad-\left(1-\mu_{i}(e)\right) \gamma(1+\gamma) \theta e\left(1-r_{i L}(e)\right)^{\delta} \mu_{i}(e)^{\gamma-1}\left[y_{H}-w_{L}\left(1-r_{i L}(e)\right)\right]^{1+\gamma} .
\end{aligned}
$$

We know that $V_{H}>V_{i L}(e)$. Therefore, a sufficient condition for (19) to be positive is:

$$
2 \mu_{i}(e)>\left(1-\mu_{i}(e)\right) \gamma
$$

or:

$$
\mu_{i}(e)>\frac{\gamma}{2+\gamma} \in(0,1)
$$

The result follows immediately. In the same way, it is straightforward to establish part (ii). 
Proof of Proposition 6 . We need only derive a condition that guarantees $r_{i L}>r_{H}$ for all $i \in I$. Write the first-order condition (21) for each $i \in I_{L}$ in a PE as:

$$
\frac{1}{1-r_{i L}}+d\left(r_{i L}\right)=F^{\prime}\left(r_{i L}\right)
$$

where:

$$
d\left(r_{i L}\right)=w_{L}(1+\gamma)\left(1-r_{i L}\right)^{\delta} \mu_{i}^{\gamma}\left(y_{H}-w_{L}\left(1-r_{i L}\right)\right)^{\gamma}-\delta\left(1-r_{i L}\right)^{\delta-1} \mu_{i}^{1+\gamma}\left(y_{H}-w_{L}\left(1-r_{i L}\right)\right)^{1+\gamma} .
$$

Recall that the first-order condition for each $i \in I_{H}$ in a $\mathrm{PE}$ is:

$$
\frac{1}{1-r_{H}}=F^{\prime}\left(r_{H}\right)
$$

Clearly, $r_{i L}>r_{H}$ if and only if $d\left(r_{i L}\right)<0$, which in turn occurs if and only if:

$$
w_{L}(1+\gamma)\left(1-r_{i L}\right) \mu_{i}^{\gamma}\left(y_{H}-w_{L}\left(1-r_{i L}\right)\right)^{\gamma}-\mu_{i}^{1+\gamma}\left(y_{H}-w_{L}\left(1-r_{i L}\right)\right)^{1+\gamma}<0,
$$

which implies that:

$$
y_{H}-y_{i L}>\frac{1+\gamma}{\delta} \frac{y_{i L}}{\mu_{i}}
$$

